\title{
Mapping inequalities in school attendance: the relationship between different dimensions of socioeconomic status and forms of school absence*
}

\author{
Markus Klein ${ }^{1}$, Edward Sosu ${ }^{1}$, Shadrach Dare \\ ${ }^{1}$ School of Education, University of Strathclyde \\ ${ }^{2}$ Institute of Biodiversity, Animal Health \& Comparative Medicine, University of Glasgow
}

March 20, 2020

\begin{abstract}
In this paper, we investigated whether and to what extent dimensions of socioeconomic background (parental education, parental class, free school meal registration, housing status, and neighborhood deprivation) predict overall school absences and different reasons for missing school (truancy, sickness, family holidays and temporary exclusion) among 4,620 secondary pupils in Scotland. Participants were drawn from a sample of the Scottish Longitudinal Study comprising linked Census data and administrative school records. Using fractional logit models and logistic regressions, we found that all dimensions of socioeconomic background were uniquely linked to overall absences. Multiple measures of socioeconomic background were also associated with truancy, sickness-related absence and temporary exclusion. Social housing and parental education had the most pervasive effect across these forms of absenteeism.
\end{abstract}

\section{Keywords}

School absences, School attendance, Truancy, School suspension, Socioeconomic status, Inequality

\footnotetext{
${ }^{*}$ This study is funded by the Economic and Social Research Council (ESRC) Secondary Data Analysis Initiative Award ES/R004943/1. We would like to thank Prof Ian Rivers and Claire Goodfellow for their valuable comments on an earlier draft of the manuscript. We are also grateful to Dr Lynne Forrest for guidance and assistance during data management and analysis. The help provided by staff of the Longitudinal Studies Centre-Scotland (LSCS) is acknowledged. The LSCS is supported by the ESRC/JISC, the Scottish Funding Council, the Chief Scientist's Office, and the Scottish Government. The authors alone are responsible for the interpretation of the data. Census output is Crown copyright and is reproduced with the permission of the Controller of HMSO and the Queen's Printer for Scotland.
} 


\section{Introduction}

School absenteeism is a pervasive problem in educational systems around the world and has attracted much attention from researchers, media, and policymakers alike (Attendance Works 2016; Gottfried and Hutt 2019; Jordan and Miller 2017; UK Department of Education 2019). In Scotland, for instance, recent increases in the number of children missing out on school due to unauthorized family holidays have brought the issue to the top of the policy agenda with media reports highlighting a record number of parents being prosecuted (BBC, 2019). In addition to family holidays, being absent from school can be due to reasons such as sickness, exclusion, or truancy.

Missing out on school has high costs for individuals and society (Reid 2005). At the individual level, early school absenteeism and exclusion are also strong predictors of subsequent poor attendance and exclusion later in school (Alexander et al. 2001; Bowman-Perrott et al. 2011). Higher rates of absenteeism are also associated with poor academic performance (e.g., Gottfried 2010; Morrissey et al. 2014; Ready 2010), school dropout (Balfanz et al. 2007; Ou and Reynolds 2008; Rumberger 1995) and lower likelihood of college enrolment (Balfanz and Byrnes 2012). In the longer term, school absenteeism is associated with substance abuse such as smoking, drinking, and taking drugs (Hallfors et al. 2002), running away from home (Tyler and Bersani 2008), and a lower likelihood of employment (Alexander et al. 1997). On a societal level, persistent school absence is linked with increased risk of juvenile delinquency (Clark et al. 2003; Zhang et al. 2007; Mueller and Stoddard 2006; McVie 2006), severe criminal activities, violence, contacts with the legal system and imprisonment (Rodríguez and Conchas 2009; Kearney 2009; Skola and Williamson 2012; Wolf and Kupchik 2017).

Regarding the determinants of school attendance, a consistent finding from the literature is the association between children's socioeconomic background and school absenteeism. While a few studies provide mixed findings (e.g., Ingul et al. 2012; Rhoad-Drogalis and Justice 2018) or suggest no relationship between socioeconomic background and absenteeism (e.g., Stempel et al. 2017), the majority of studies found a strong association (e.g., Gennetian et al. 2018; Gottfried and Gee 2017; Gubbels et al. 
2019; Morrissey et al. 2014). Students from lower socioeconomic backgrounds are over-represented among those absent from school and have a higher risk of school absenteeism than those from more advantaged socioeconomic backgrounds.

One explanation for this association is that children from lower socioeconomic backgrounds are at a greater risk of developing behavior problems that are known risk antecedents of being absent or excluded from school (Classi et al. 2012; Corville-Smith et al. 1998; Gubbels et al. 2019; Hemphill et al. 2014; Ingul et al. 2012). Socioeconomic background is also associated with several other predictors of school absenteeism such as substance abuse (Engberg and Morral 2006; Goodman and Huang 2015), child and adolescent health (Currie et al. 2009; Duong et al. 2015; Echeverría et al. 2014; Moonie et al. 2006), frequent school transfers (Alexander et al. 1996; Nolan et al. 2013), exposure to environmental hazards (Chen et al. 2002; Gilliland et al. 2001), run-down school facilities (DuránNarucki 2008), reduced access to public transport (Gottfried 2017; Stein and Grigg 2019) and exposure to crime (Burdick-Will et al. 2019).

However, our review of the literature suggests that several gaps in our understanding of the association between socioeconomic background and school absences remain. First, the vast majority of the literature has emanated from the US (e.g., Gennetian et al. 2018; Gottfried and Gee 2017; Morrissey et al. 2014). Within the context of the UK, we only found a limited number of research studies exploring the association between children's socioeconomic characteristics and truancy (Attwood and Croll 2006) or exclusion (Paget et al. 2017; Strand and Fletcher, 2014). To our knowledge, there are no existing studies from Scotland despite trends showing a general increase in unexplained absences, including truancy from 2005/06 to 2016/17 academic year (Scottish Government 2010, 2017).

Second, research investigating socioeconomic inequalities in school attendance rarely looked at the impact of different dimensions of socioeconomic background on absences in the same study. The majority of studies used only one measure of socioeconomic background (e.g., eligibility for free and reduced-price lunch in school) when analyzing associations with school absences. Studies that considered multiple measures of socioeconomic background combined them in most cases as a composite score 
(Achilles et al. 2007; Gottfried and Gee 2017; Ready 2010; for exceptions, see Rhoad-Drogalis and Justice 2018 on absenteeism among preschool children; Sullivan et al. 2013 on school suspension). A limitation of this approach is that it ignores the unique effects of individual socioeconomic dimensions. Evidence from studies of the association between socioeconomic background and developmental or educational outcomes (Bukodi and Goldthorpe 2013; Schenck-Fontaine and Panico 2019) suggests that different components of socioeconomic background are likely to influence school absenteeism independently from each other and to a varying extent. Hence, neglecting critical dimensions of socioeconomic background may lead to an underestimation of the full scope of the relationship between socioeconomic background and school attendance, and prevent us from understanding the various layers of social inequality.

Third, studies exploring the link between socioeconomic background and school absences focus on either overall measures of absenteeism or specific forms (e.g., truancy). They hardly address whether and to what extent socioeconomic background is associated with different reasons for being absent from school (for an exception see Gottfried 2009). Even rarer are studies exploring associations between different dimensions of socioeconomic background and forms of school absenteeism in a single study. The impact of socioeconomic background on school absences may be smaller or larger, depending on the form of absenteeism considered.

Fourth, intersectional perspectives (e.g., Codiroli Mcmaster and Cook 2018) suggest that socioeconomic circumstances influence adolescents' life courses in conjunction with other individual and family characteristics. The strength of the relationship between socioeconomic background and school absenteeism may vary depending upon pupils' sex (e.g., Attwood and Croll 2006; Hemphill et al. 2010) or place of residence (Achilles et al. 2007). Whereas there is literature on the separate effects of socioeconomic background, sex, and place of residence on school absenteeism, the question of whether socioeconomic inequalities in adolescents' school attendance differ across sex and place of residence has attracted much less attention. 
Since behavioral development among boys is more susceptible to family circumstances than the behavior of their female counterparts (Autor et al. 2016), boys from lower socioeconomic backgrounds will be at a higher risk of developing behavioral problems (Brooks-Gunn and Duncan 1997; Mazza et al. 2017) that exacerbate the risk of truancy or exclusion. On the contrary, the socioeconomic background may have a more detrimental effect on girls than on boys in the case of sickness-related absenteeism. 'Period poverty' - where girls are unable to access sanitary products due to financial constraints (Plan International UK 2017; WHO/UNICEF 2012) - may increase the likelihood of school absenteeism among girls from lower socioeconomic backgrounds.

Moreover, the relationship between socioeconomic background and school absenteeism may be less pronounced in rural than in urban areas. Rural areas are less exposed to crime, neighborhood problems (e.g., litter, graffiti), air pollution, or income deprivation and have a greater community sense than urban areas (Scottish Government 2018b). These factors are likely to serve as a protective buffer against absenteeism for students from lower socioeconomic backgrounds in rural areas.

\section{The Current Study}

The current study aims to fill the research gaps mentioned above and to contribute to our understanding of the association between socioeconomic background and school attendance in several ways. First, our paper adds to the literature by investigating the socioeconomic determinants of school absences for adolescent pupils in Scotland. We use the Scottish Longitudinal Study linking Census data and administrative school records, allowing us to harness reliable and comprehensive measures of socioeconomic background from the Census and of school attendance from the administrative data. Second, we investigate how different dimensions of socioeconomic background (social class, parental education, free school meal registration, housing status, and neighborhood deprivation) uniquely shape the risk of absences. Third, we consider both overall absenteeism and the different reasons for being absent from school (truancy, sickness-related absence, family holidays, and temporary exclusion) and 
explore how they are associated with different dimensions of socioeconomic background. Fourth, drawing on notions of intersectionality, we investigate whether sex and place of residence moderate the relationship between dimensions of socioeconomic background and forms of school absenteeism.

\section{Research questions}

In summary, the current study aims to understand the nature of socioeconomic inequalities in school attendance among adolescents in their final year of compulsory schooling in Scotland. We ask the following research questions:

1. Is there a relationship between socioeconomic background and school attendance in Scotland?

2. Do patterns differ by the dimensions of socioeconomic background measured (parental education, parental class, free school meal registration, neighborhood deprivation, housing status)?

3. Are there differences in the association between dimensions of socioeconomic background and forms of school absenteeism in Scotland (sickness absence, family holidays, truancy, temporary exclusion)?

4. Do sex and place of residence moderate the relationship between dimensions of socioeconomic background and forms of absenteeism?

\section{Methods}

\section{Data and sample}

This research uses data from the Scottish Longitudinal Study (SLS), which is a large-scale anonymized record linkage study in Scotland. The SLS covers 5.3\% of the Scottish population, selected by using 20 semi-random birthdates. Data can be linked from current statistical and administrative sources such as national Census data (1991, 2001, 2011), vital events data, the National Health Service (NHS) central register data, or school education data (2007-2013). SLS linked datasets have no 
identifiable individual level data and are derived from linkages that are anonymized prior to handover to the research team.

Our SLS sub-sample consists of two cohorts of SLS members who were in their final year of compulsory schooling (S4) in state-funded schools in 2007 and 2008, respectively ( $n=6,031)$. At this stage, almost all students in Scotland undertake high stakes examinations, which strongly determine their future educational and labor market pathways (Iannelli and Duta 2018). In this paper, we used information from the Census 2001 data on these SLS members and their parents' socioeconomic characteristics, information from the School Census and their attendance data from the years 2007 and 2008.

We excluded pupils who attended special schools, those recorded to have repeated a school year, and those who appeared to have skipped a consecutive school stage from our analytic sample $(\mathrm{n}=62)$. These groups may differ systematically from the majority regarding social characteristics and school attendance. Pupils who were not present $(n=812)$ or who did not live with their parents $(n=214)$ during the 2001 national Census were also not included in our sample. We also excluded pupils due to non-response (missing/edited) on any of the variables used $(n=323)$. The most common variables affected by nonresponse (missing/edited) were parental class, education, and mother's age. Our final sample, therefore, consists of 4,620 pupils.

We obtained ethical approval for the study from the University of xxxx (removed for blind review) ethics committee. The SLS Research Board gave their approval for the use of SLS data for the project $\operatorname{xxxx}$ (removed for blind review). All analyses took place in a Safe Setting Place following established protocols set up by the data holders for the safe use of the data for research purposes (SLSDSU n.d.). 


\section{Variables}

Our dependent variable consists of overall absenteeism as well as specific reasons for being absent from school (sickness-related absence, truancy, temporary exclusion). To capture the different dimensions of socioeconomic background, we considered parental education, parental class, free school meal registration, housing tenure, and neighborhood deprivation. We used Cramer's V to calculate correlation coefficients to assess potential multicollinearity among our dimensions of socioeconomic background. Our dimensions of socioeconomic background are correlated, but they are not multicollinear. The average correlation among all dimensions of socioeconomic background was $0.34(\operatorname{Min}=0.22$; $\operatorname{Max}=0.49)$. The full correlation matrix is presented in the Supplementary Material (Table S1).

\section{Overall absenteeism}

Overall absenteeism was measured as the proportion of half-days a pupil was absent from school in their final year of compulsory schooling, regardless of the reason for being absent. The total number of halfdays attended includes attendance in school, educational visits organized by the school, other attendance out of school, medical and dental appointments lasting less than half of a school opening day. To account for differences in the number of possible half-days between different school authorities and students, we divided the total number of half-days attended by the total number of possible half-days for each student in a given school authority. We subtracted the resulting proportion from one to obtain the proportion of overall absenteeism. On average, the percentage of half-days students missed in the final year of compulsory schooling was 14 percent $($ Mean $=0.14 ; \mathrm{SD}=0.13)$.

\section{Sickness-related absence}

Sickness-related absence refers to the proportion of half-days, a pupil was absent from class due to sickness and for which no educational arrangement was provided. This includes any time where a pupil is off sick, with proof of illness such as a parental letter or medical certificate. On average, the percentage of 
half-days students missed school due to sickness absence in the final year of compulsory schooling was five percent $($ Mean $=0.05 ; \mathrm{SD}=0.07)$.

\section{Family holidays}

Absence due to family holidays is a binary variable indicating whether families have taken their children out of school to go on holidays (authorized and unauthorized) at least once during the final year of compulsory schooling or not. The percentage of adolescents that were taken out of school due to family holidays was 15 percent.

\section{Truancy}

Truancy measures the proportion of half-days a student was absent and for which the student did not provide an adequate explanation. On average, the percentage of half-days students missed due to truancy in the final year of compulsory schooling was two percent $($ Mean $=0.02 ; \mathrm{SD}=0.05)$.

\section{Temporal exclusion}

Temporal exclusion refers to a situation in which a student is suspended from school for a fixed period. It was measured as a binary variable indicating whether a student had ever been excluded (1) or not excluded (0) during the school year. The percentage of students that were temporarily suspended from school at least once in the final year of compulsory schooling was five percent.

\section{Parental education}

Parental education was measured using the highest educational qualification among parents, and the educational qualification of the present parent in single-parent households at the Census 2001. It was measured with five categories: (1) No qualification (14\%); (2) Lower secondary qualification (Standard Grade/GCSE or equivalent) (31\%); (3) Upper secondary qualification (Higher Grade/A-levels or equivalent) (18\%); (4) College below degree (HNC/HND or equivalent) (11\%); and (5) First degree/Higher degree or equivalent (27\%). Highly educated parents have detailed formal and informal 
knowledge of the education system and more aware of the benefits of education for future life course outcomes. As a result, highly educated parents tend to be more involved in their children's schooling (e.g. Jeynes 2005) which, in turn, lowers their risk of being absent from school (Epstein and Sheldon 2002).

\section{Parental class}

We measured parental social class using the 5-class 'analytical' version of the National Statistics Socioeconomic Classification (NS-SEC) (Goldthorpe 2007) based on employment characteristics in the Census 2001. The specific class categories in our study were: (1) Higher managerial, administrative and professional occupations (41\%), (2) Intermediate occupations (15\%), (3) Small employers and own account workers (7\%), (4) Lower supervisory and technical occupations (9\%), (5) Semi-routine and routine occupations $(27 \%)$. We used the highest class among both parents and, in the case of single-parent households, the class of the present parent. Parents' class position captures differences in employment relations that are associated with advantages and disadvantages in income security, short-term income stability, and longer time income prospects (Goldthorpe and McKnight 2006). Economic stability may reduce family stress, which is associated with risk antecedents of school absenteeism (Classi et al. 2012; Gubbels et al. 2019; Hemphill et al. 2014; Ingul et al. 2012).

\section{Free school meal registration}

Free school meal (FSM) registration was measured as a binary variable indicating whether a student was registered as entitled to free school meals (1) or not (0) during the final year of secondary schooling. This information was taken from the School Census. In 2007/2008, pupils entitled to free school meals were living in families who received Income Support (IS) or Income-based Job Seekers Allowance (IBJSA). Pupils with parents or carers who received Child Tax Credit, who did not receive Working Tax Credit, and had an annual income of below $£ 14,155$ were also entitled to FSM. Other than social class, FSM eligibility identifies students currently living in low-income and out-of-work households (Hobbs and Vignoles 2010). It is a marker of current hardship that has immediate negative consequences for health 
and living conditions, which may lead to lower school attendance among children. However, not all students who may be eligible for free school meals are registered (McKendrick et al., 2019). In our analytical sample, nine percent of students claimed free school meals.

\section{Housing tenure}

We measured housing tenure using information from the 2001 Census to indicate whether participants were living in socially rented accommodation (1) or in an owner-occupied or privately rented accommodation (0). Families living in social housing are more likely to be relatively poor than families living in other forms of housing tenure (Tunstall et al. 2013). Social housing is also a risk factor for falling into poverty in the future (Jenkins, 2011). Although social housing is aimed at providing lowincome families with better accommodation, some studies suggest that they lead to residential segregation and a higher concentration of families living in poverty (Newman 2008). In our analytical sample, 28 percent of pupils lived in social housing in the Census 2001.

\section{Neighborhood deprivation}

Neighborhood deprivation was measured using the Scottish Index of Multiple Deprivation (SIMD) from the 2001 Census. The SIMD ranks 6,505 small areas, each containing around 350 households from most deprived to least deprived according to seven life course domains (employment; income; health; education, skills, and training; geographic access to services; crime; housing). For the current study, we used SIMD quintiles ranging from most deprived (SIMD 1) to least deprived (SIMD 5) neighborhood (\% SIMD $1=21 ; \%$ SIMD $2=21 ; \%$ SIMD $3=20 ; \%$ SIMD $4=19 ; \%$ SIMD $5=18 \%$ ). Neighborhood conditions are associated with differences in exposure to environmental hazards, poor access to public transport and exposure to crime, which are known risk factors for school absenteeism (Burdick-Will et al. 2019; Chen et al. 2002; Stein and Grigg 2019). 


\section{Confounders}

We adjust our multivariable analysis with the following confounders: student sex (53\% boys; $47 \%$ girls), place of residence (22\% rural; $78 \%$ urban), ethnicity derived from parental information (97\% "White"; 3 \% "Other ethnic background"), the age of the child at the start of secondary schooling (Mean $=14.06$ years; $S D=0.28)$, mothers' age at birth of the pupil (Mean $=27.85$ years; $S D=5.03)$. Since data were used from two school cohorts in the final year of compulsory schooling (50\% 2007 cohort; 50\% 2008 cohort), we controlled for this in all analyses. Table 1 summarizes the descriptive statistics of all our variables.

\section{Analytic strategy}

We used fractional logit models to analyze the association between our five socioeconomic dimensions and overall absenteeism, sickness-related absenteeism, and truancy. Fractional response models allowed us to analyze dependent variables that are measured as proportions, i.e., they include values between zero and one (Papke and Wooldridge 1996). Regarding our binary dependent variables of temporary exclusion and family holidays, we used logistic regressions. Estimates are shown as average marginal effects (AMEs) indicating average differences in the rate of absenteeism overall, sicknessrelated absences, and truancy or in the risk of temporary exclusion and family holidays holding confounders constant. AMEs can be interpreted as percentage point differences in the rate or probability of the outcome when multiplied by 100. Other than logit coefficients, they allow for comparison of estimates across different groups, in our case, sex and place of residence (Mood 2010). To account for the nested nature of the data (pupils within schools), we clustered standard errors at the school level. 
Table 1. Summary Statistics $(n=4,620)$

\begin{tabular}{|c|c|c|}
\hline & Mean/Proportion & SD \\
\hline Overall absenteeism & 0.14 & 0.07 \\
\hline Sickness-related absenteeism & 0.05 & 0.07 \\
\hline Family holidays & 0.15 & \\
\hline Truancy & 0.02 & 0.05 \\
\hline Temporary exclusion & 0.05 & \\
\hline \multicolumn{3}{|l|}{ Parental education } \\
\hline No qualification & 0.14 & \\
\hline Lower secondary qualification & 0.31 & \\
\hline Upper secondary qualification & 0.18 & \\
\hline College below degree & 0.11 & \\
\hline First degree/Higher degree & 0.27 & \\
\hline \multicolumn{3}{|l|}{ Parental class } \\
\hline $\begin{array}{l}\text { Higher managerial, administrative and } \\
\text { professional occupations }\end{array}$ & 0.41 & \\
\hline Intermediate occupations & 0.15 & \\
\hline Small employers and own account workers & 0.07 & \\
\hline Lower supervisory and technical occupations & 0.09 & \\
\hline Semi-routine and routine occupations & 0.27 & \\
\hline \multicolumn{3}{|l|}{ Free school meal registration } \\
\hline Yes & 0.09 & \\
\hline No & 0.91 & \\
\hline \multicolumn{3}{|l|}{ Housing tenure } \\
\hline Social rented & 0.28 & \\
\hline Private rented/owned & 0.72 & \\
\hline \multicolumn{3}{|l|}{ Scottish Index of Multiple Deprivation } \\
\hline SIMD 1 (most deprived) & 0.18 & \\
\hline SIMD 2 & 0.19 & \\
\hline SIMD 3 & 0.22 & \\
\hline SIMD 4 & 0.20 & \\
\hline SIMD 5 (least deprived) & 0.21 & \\
\hline \multicolumn{3}{|l|}{ Sex } \\
\hline Female & 0.47 & \\
\hline Male & 0.53 & \\
\hline \multicolumn{3}{|l|}{ Place of residence } \\
\hline Urban & 0.78 & \\
\hline Rural & 0.22 & \\
\hline \multicolumn{3}{|l|}{ Ethnicity } \\
\hline "White" & 0.97 & \\
\hline "Other ethnic background" & 0.03 & \\
\hline Child's age at start of secondary schooling & 14.06 & 0.28 \\
\hline Mother's age at birth & 27.85 & 5.03 \\
\hline \multicolumn{3}{|l|}{$\begin{array}{l}\text { School cohort in final year of secondary } \\
\text { schooling }\end{array}$} \\
\hline 2007 & 0.50 & \\
\hline 2008 & 0.50 & \\
\hline
\end{tabular}

Source. Scottish Longitudinal Study, own calculations. 
We analyzed all dimensions of socioeconomic background (neighborhood deprivation, parental education, parental class, FSM registration, housing tenure) simultaneously when predicting the different forms of absenteeism (overall absenteeism, sickness-related absenteeism, family holidays, truancy, and temporary exclusion). To assess the moderating effects of these variables on the relationship between dimensions of socioeconomic background and forms of school absenteeism, we also stratified our analysis by sex and place of residence. Our findings are presented as coefficient plots for ease of comparison of effect sizes. It also allowed us to directly compare estimates for the dimensions of socioeconomic background across moderators. Full regression outputs, including all confounders, can be found in the Supplementary Material (Tables S2-S6).

\section{Results}

\section{Socioeconomic background and overall absenteeism}

All of the socioeconomic dimensions investigated, neighborhood deprivation, parental education, social class, housing tenure, and FSM registration were uniquely associated with overall absenteeism. Adolescents from more deprived areas, living in socially rented housing, coming from households with lower levels of parental education and social class, and registered for FSM were more frequently absent from school than their peers from more advantaged backgrounds. Only adolescents closer to the highest socioeconomic group in the neighborhood, education, and class categories did not deviate significantly from the reference group (i.e., highest socioeconomic group). As seen in Figure 1 (left-hand graph), the average marginal effects (AMEs) for our dimensions of socioeconomic background and overall absenteeism were largest for adolescents from socially rented households (AME=0.043, SE=0.005), households with no qualifications ( $\mathrm{AME}=0.041, \mathrm{SE}=0.008$ ), registered for FSM (AME=0.037, $\mathrm{SE}=0.008)$, growing up in the most deprived area $(\mathrm{AME}=0.029, \mathrm{SE}=0.007)$, and households with routine or semi-routine occupations $(\mathrm{AME}=0.020, \mathrm{SE}=0.006)$. 
Figure 1. Associations between dimensions of socioeconomic background and overall absenteeism (with 95\% confidence intervals)

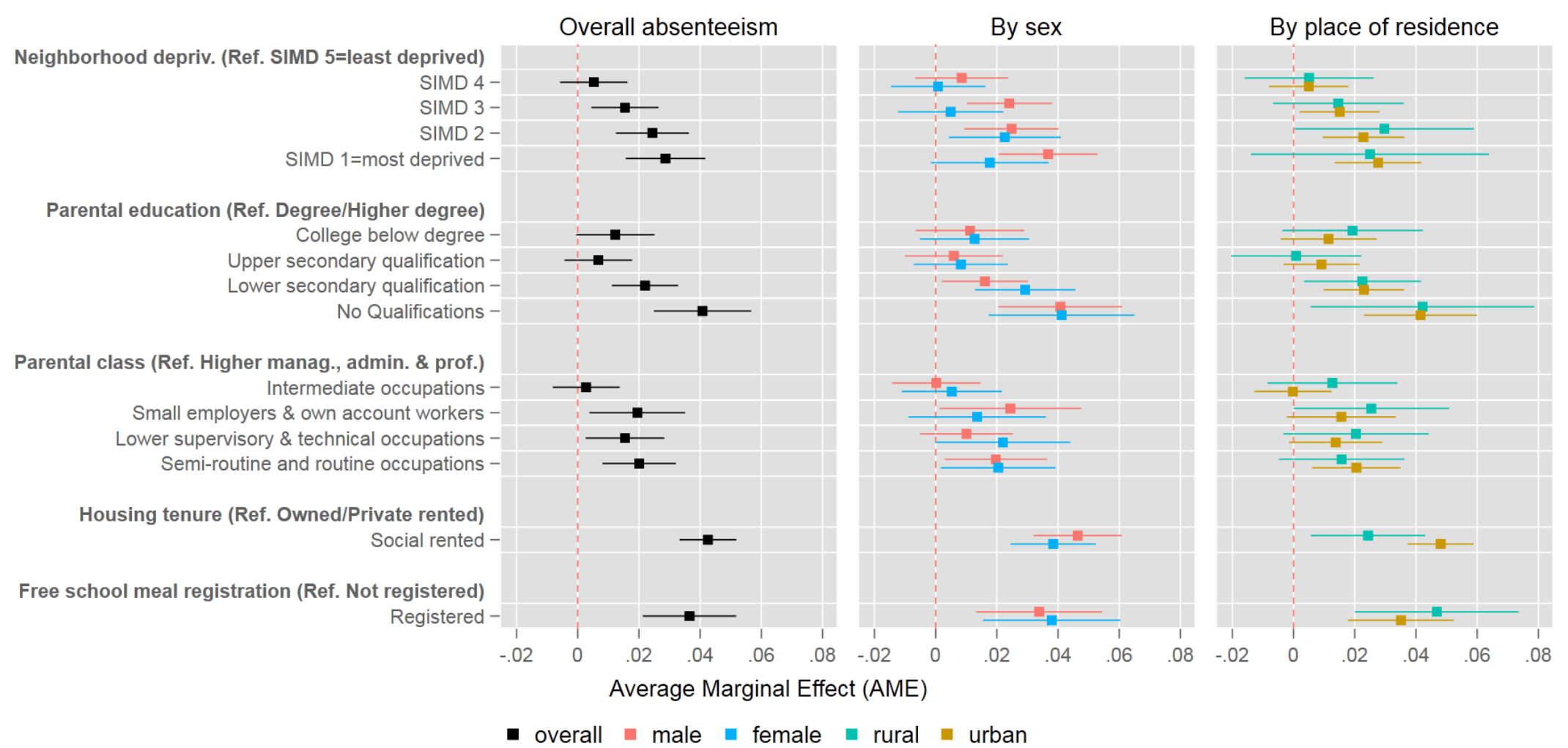

Source. Scottish Longitudinal Study, own calculations. 
Regarding our covariates of interest (see Table S2 in the Supplementary Material), girls are more frequently absent from school compared to boys ( $\mathrm{AME}=0.011, \mathrm{SE}=.0004$ ), and adolescents from rural areas had lower levels of overall absenteeism in comparison to their urban peers (AME $=-0.022$, $\mathrm{SE}=0.005$ ). Analyses stratified by sex showed similar patterns in the association between dimensions of socioeconomic background and school absenteeism among girls and boys (middle graph in Figure 1). The effect of socioeconomic indicators on overall school absenteeism was also similar for adolescents growing up in urban and rural areas (right-hand graph in Figure 1). The only exception is that living in socially rented housing seems to have a stronger association with overall absenteeism for adolescents growing up in urban areas compared to those growing up in rural areas (AME=0.048; $\mathrm{SE}=0.005$ vs. $\mathrm{AME}=0.024, \mathrm{SE}=0.010)$.

\section{Socioeconomic background and sickness-related absence}

Figure 2 (left-hand graph) indicates the relationship between our dimensions of socioeconomic background and sickness-related absenteeism. Only parental education, housing tenure, and FSM registration were more strongly associated with sickness absenteeism. Higher rates of sickness absenteeism were reported for adolescents from households with lower parental education (AME=0.013, $\mathrm{SE}=0.003$ for lower secondary qualification; $\mathrm{AME}=0.015, \mathrm{SE}=0.005$ for no qualifications). Adolescents living in socially rented accommodations ( $\mathrm{AME}=0.017, \mathrm{SE}=.003$ ) and those registered for FSM $(\mathrm{AME}=0.011 ; \mathrm{SE}=0.004)$ also had a higher level of sickness-related absenteeism. Neighborhood deprivation and parental social class were no strong predictors of sickness-related absenteeism.

Regarding our moderators (see Table S3 in the Supplementary Material), girls had significantly higher levels of sickness absenteeism in comparison to boys (AME=0.011, $\mathrm{SE}=0.002$ ), and there were no differences in the rate of sickness absenteeism between adolescents growing up in urban and rural areas $(\mathrm{AME}=0.000, \mathrm{SE}=0.003)$. 
Figure 2. Associations between dimensions of socioeconomic background and sickness-related absenteeism (with 95\% confidence intervals)

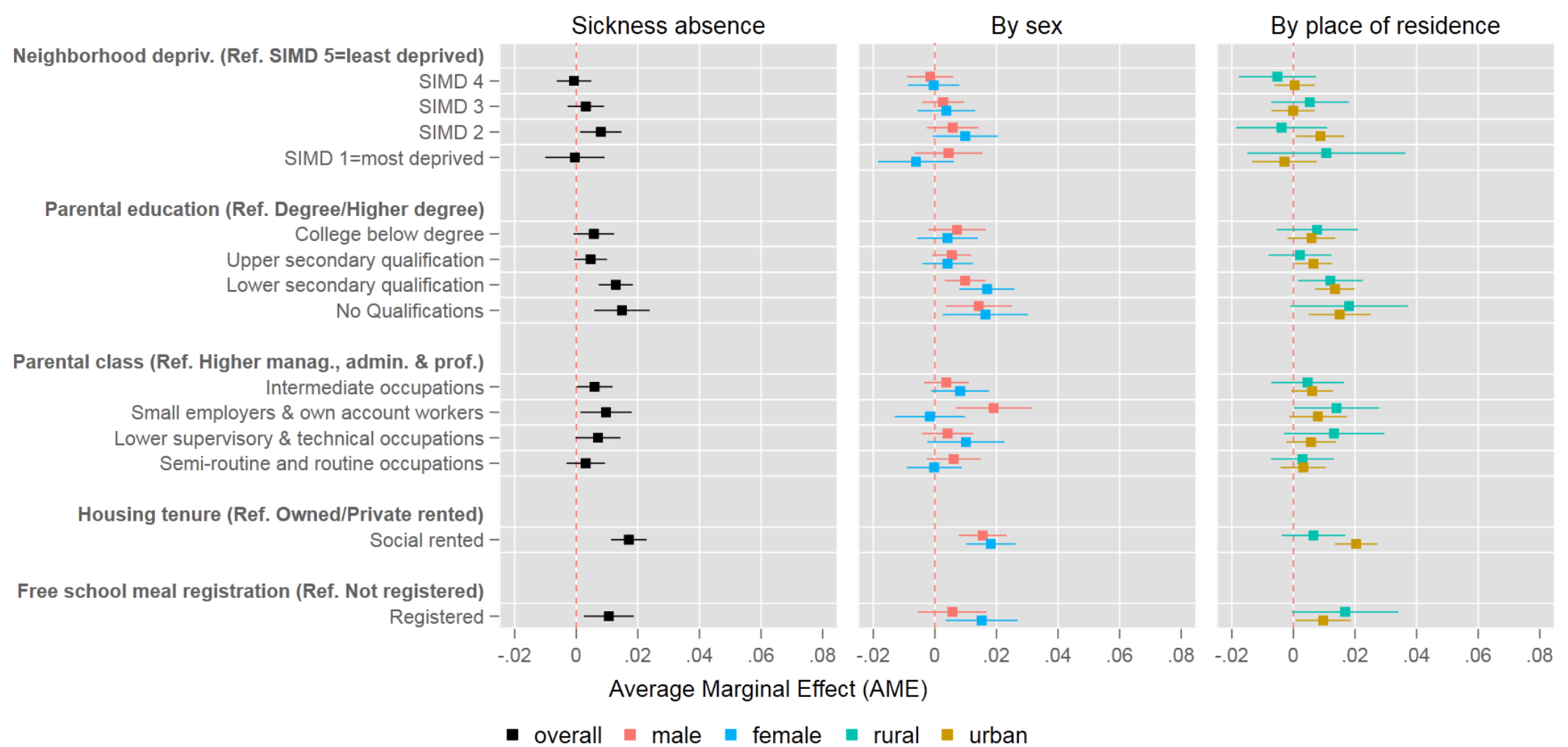

Source. Scottish Longitudinal Study, own calculations. 
Figure 2 (middle and right-hand graph) shows that the association between the socioeconomic indicators and sickness absenteeism was similar for boys and girls, as well as for adolescents growing up in rural and urban areas. There were two exceptions to these patterns. Regarding sex differences, FSM registration was more strongly associated with sickness absenteeism among girls than among boys $(\mathrm{AME}=0.015, \mathrm{SE}=0.006$ vs. $\mathrm{AME}=0.006 ; \mathrm{SE}=0.006)$. As with overall absenteeism, adolescents living in socially rented housing were more likely to be absent due to sickness in urban areas than their peers in rural areas $(\mathrm{AME}=0.020 ; \mathrm{SE}=0.004$ vs. $\mathrm{AME}=0.007, \mathrm{SE}=0.005)$.

\section{Socioeconomic background and absences due to family holidays}

Figure 3 shows that absences due to family holidays are not stratified by socioeconomic background. Aside from FSM registration, none of our indicators were strongly related to missing out on school due to family holidays. Adolescents on FSM registration were less likely to be absent due to family holidays than their peers not registered for FSM (AME=-0.046, $\mathrm{SE}=0.018)$. The main effects of our moderators can be found in the Supplementary Material Table S4. While families decided more often to take girls on term-time holidays than boys ( $\mathrm{AME}=0.025, \mathrm{SE}=0.011$ ), there was no difference between families in rural and urban areas in their probability of going on holidays during the school year (AME=0.001, SE=0.015). As shown in the middle and right-hand graph of figure 3, sex and place of residence did not moderate the relationship between our dimensions of socioeconomic background and absences due to family holidays in any consistent or considerable way. 
Figure 3. Associations between dimensions of socioeconomic background and absenteeism due to family holidays (with $95 \%$ confidence intervals)

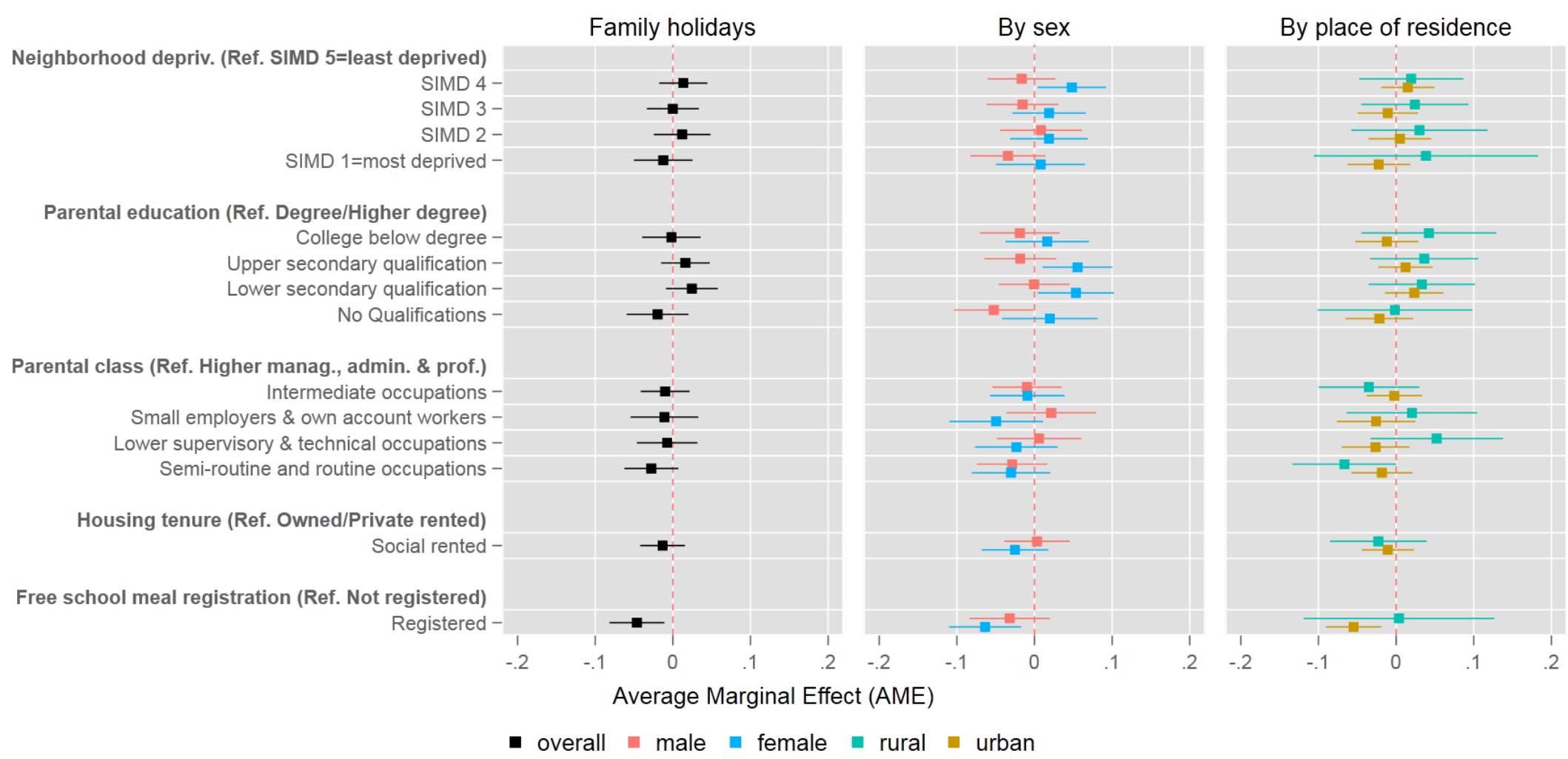

Source. Scottish Longitudinal Study, own calculations. 


\section{Socioeconomic background and truancy}

Figure 4 (left-hand graph) depicts the relationship between socioeconomic background and truancy. Only parental education, parental class, and housing tenure were more strongly associated with truancy. Adolescents whose parents had no qualifications were more frequently truant than adolescents whose parents had a first degree (AME=0.009; $\mathrm{SE}=0.004)$. Adolescents whose parents work in semi-routine and routine occupations had higher levels of truancy than their peers with parents in professional and managerial occupations ( $\mathrm{AME}=0.007, \mathrm{SE}=0.003$ ). For both parental education and class, the intermediate categories were not much different from the reference group. Adolescents growing up in socially rented housing were also more frequently truant than their peers growing up in owned or privately rented accommodations $(\mathrm{AME}=0.008, \mathrm{SE}=0.002)$.

The main effects for our moderators of sex and place of residence on truancy can be found in Table S5 in the Supplementary Material. There were no greater sex differences in the extent of truancy $(\mathrm{AME}=0.003, \mathrm{SE}=0.002)$. Also, adolescents from rural and urban areas did not differ significantly in the rate of truancy ( $\mathrm{AME}=-0.003, \mathrm{SE}=0.002$ ). Figure 4 (middle and left-hand graph) shows that the association between our socioeconomic dimensions and truancy was similar for males and females, as well as for adolescents growing up in rural and urban areas.

\section{Socioeconomic background and temporary exclusion}

When looking at temporary exclusion (left-hand graph in Figure 5), we found that living in deprived areas, having parents with no qualifications, being registered for FSM, and growing up in socially rented housing substantially increases the risk of being temporarily excluded from school. Being registered for FSM was the strongest predictor of temporary exclusion. Adolescents that are registered for free school meals had a higher probability of being temporarily excluded (4.1 percentage points) than peers not registered for FSM (AME=0.041, SE=0.014). Having parents with no qualifications increased the risk of temporary exclusion by 3.4 percentage points $(\mathrm{AME}=0.034, \mathrm{SE}=0.014)$. Growing up in social housing or in more deprived areas increased the risk of temporary exclusion by more than two percentage points 
Figure 4. Associations between dimensions of socioeconomic background and truancy (with 95\% confidence intervals)

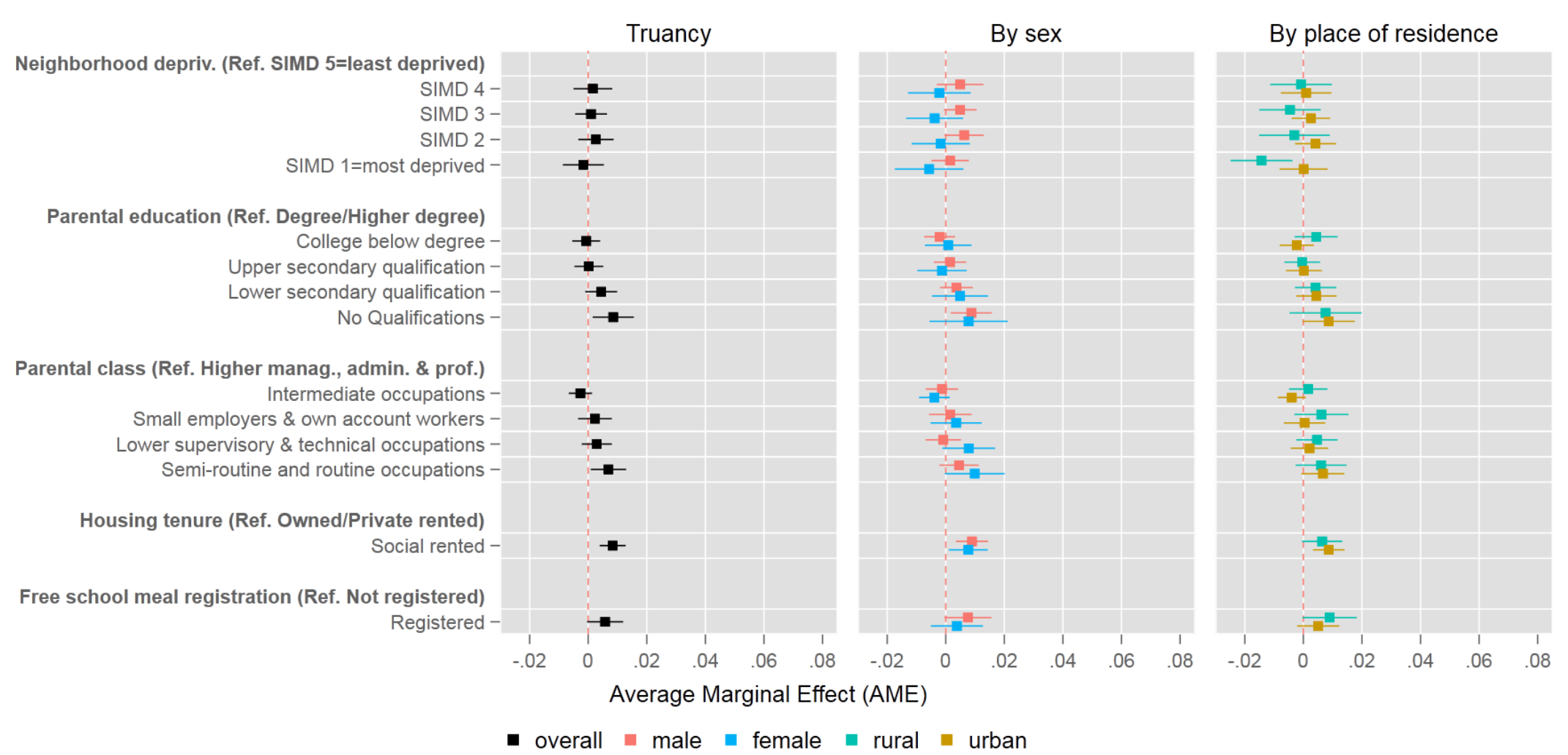

Source. Scottish Longitudinal Study, own calculations. 
(AME=0.020, $\mathrm{SE}=0.009$ for social housing; $\mathrm{AME}=0.021, \mathrm{SE}=0.010$ for $\mathrm{SIMD} 3$; $\mathrm{AME}=0.028, \mathrm{SE}=0.011$

for SIMD 2; $\mathrm{AME}=0.024, \mathrm{SE}=0.012$ ). Adolescents whose parents are employed in lower supervisory and technical occupations had a risk that is 3.7 percentage points higher than those having parents from professional and managerial occupations ( $\mathrm{AME}=0.037, \mathrm{SE}=0.014)$. Apart from this exception, social class was a weaker predictor of temporary exclusion.

As shown in Table S6 in the Supplementary Material, girls had a lower probability of being excluded from school than boys (AME=-0.054, $\mathrm{SE}=.0006$ ), while no meaningful differences in exclusion among adolescents growing up in urban and rural areas exist (AME=0.001, $\mathrm{SE}=0.008$ ). There were some differences in the pattern of association between our socioeconomic dimensions and temporary exclusion by sex. There was, for instance, a tendency for neighborhood deprivation (e.g. AME=0.044, SE=0.020 vs. $\mathrm{AME}=0.002, \mathrm{SE}=0.013$ for SIMD 1), parents with no qualifications (AME=0.057, $\mathrm{SE}=0.022$ vs. $\mathrm{AME}=0.007, \mathrm{SE}=0.013)$, and $\mathrm{FSM}$ registration $(\mathrm{AME}=0.054, \mathrm{SE}=0.022$ vs. $\mathrm{AME}=0.028, \mathrm{SE}=0.013)$ to be more strongly associated with the risk of temporary exclusion among boys than among girls (Figure 5, middle graph). Analyses stratified by place of residence suggest similar patterns in the association between socioeconomic indicators and temporary exclusion (Figure 5, right-hand graph).

\section{Discussion}

In this paper, we investigated the association between socioeconomic background and school absences among pupils in their final year of secondary schooling in Scotland. To do so, we used a unique nationally representative dataset that combines information from Census data with administrative school records. Our study contributes new evidence on socioeconomic inequalities in school attendance by focusing on a country outside of the commonly considered context. Additionally, most previous research used a single measure of socioeconomic background in their analysis and thus ignored the multidimensional nature of family background. We advance the knowledge in the field by exploring the extent to which different dimensions of socioeconomic background (social class, parental education, free 
Figure 5. Associations between dimensions of socioeconomic background and temporal exclusion (with 95\% confidence intervals)

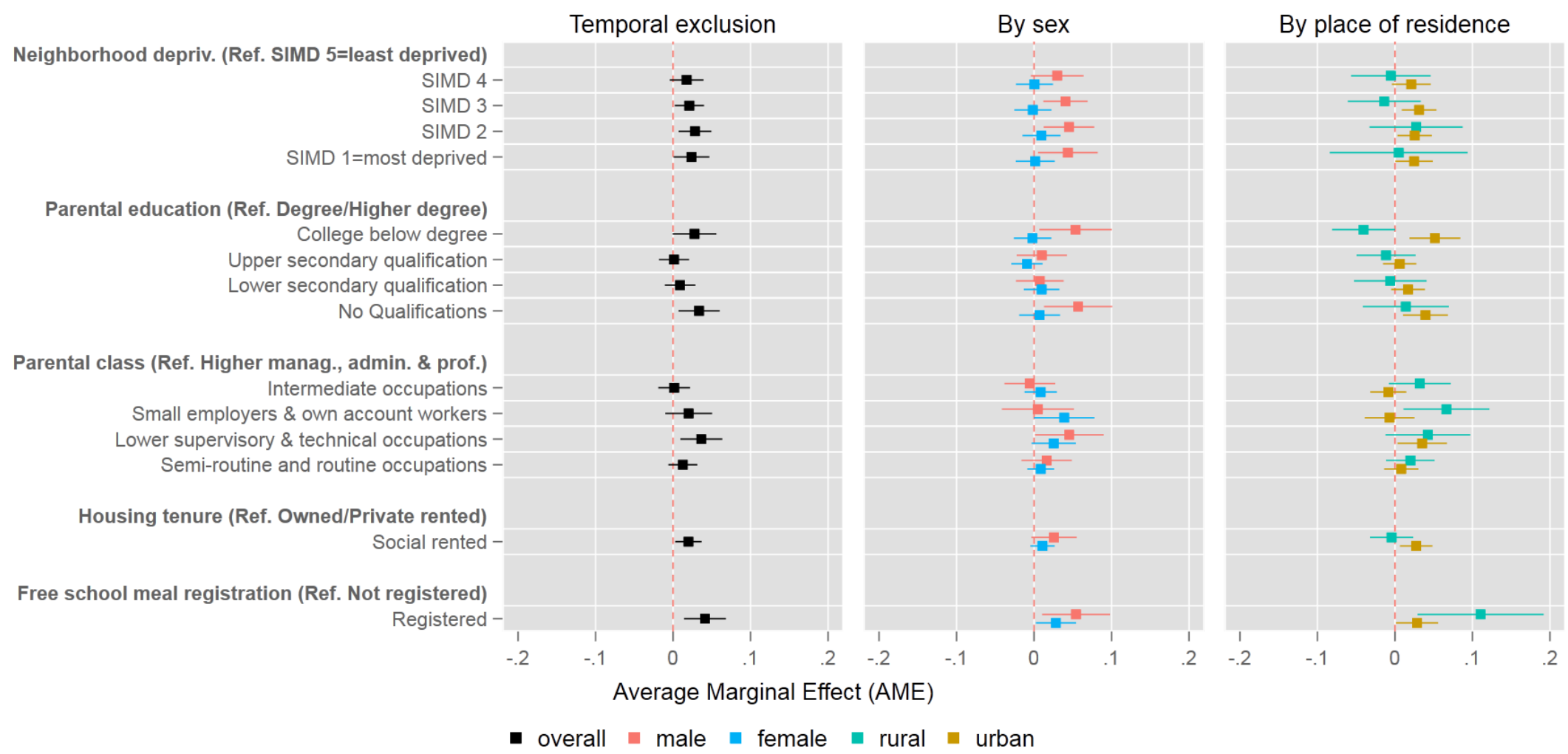

Source. Scottish Longitudinal Study, own calculations. 
school meal registration, housing status, and neighborhood deprivation) were associated with school absences. Further, while previous studies focus on either overall absenteeism or a specific form of absenteeism (e.g., truancy), we looked at a number of different reasons for being absent from school and their associations with dimensions of socioeconomic background. Finally, we also analyzed whether sex and place of residence moderated the link between socioeconomic background and school absenteeism.

The results confirm previous studies in other contexts, mainly the US (e.g., Gennetian et al. 2018; Gottfried and Gee 2017; Morrissey et al. 2014) that socioeconomic background is a significant predictor of being absent from school. A unique finding from our study is that all dimensions of socioeconomic background, including neighborhood deprivation, are independently associated with overall absenteeism. In line with emergent evidence in other areas (Bukodi and Goldthorpe 2013; Schenck-Fontaine and Panico 2019), our findings demonstrate that focusing on a single measure of socioeconomic background can lead to an underestimation of the full scope of socioeconomic inequality in school absenteeism.

Apart from family holidays, specific forms of absenteeism were associated with multiple measures of socioeconomic background. However, only housing tenure and parental education were consistently associated with sickness-related absences, truancy, and temporary exclusion. The significance of the other dimensions of socioeconomic background explored in this study appears to be dependent on the particular form of absenteeism. It thus seems essential to take into account a variety of socioeconomic characteristics as selecting one over the other may influence whether one finds a strong relationship or not. To fully understand the association between socioeconomic background and school attendance, research has to take into account the multidimensionality of both socioeconomic background and the reasons for being absent from school.

We also examined whether sex and place of residence moderated the relationship between socioeconomic background and school absenteeism. Overall, the association between the dimensions of socioeconomic background and forms of absenteeism did not vary considerably between boys and girls. However, there were a few exceptions in line with expectations. For sickness-related absenteeism, we found that FSM registration was more strongly associated with being absent from school among girls than 
among boys. For temporary exclusion, there was a tendency for boys living in deprived areas and on FSM registration to be more at risk of being excluded than for girls growing up in the same conditions.

Regarding place of residence, there were generally no differences in the association between socioeconomic background and school attendance between urban and rural areas. We expected this relationship to be stronger in urban than in rural areas. The only exception we found is socially rented housing, which appears to have a more detrimental impact on overall absenteeism and sickness-related absence in urban than in rural areas. While these associations are not strong and pervasive enough to confirm our theoretical assumptions, more work is needed to understand the intersectional effects of socioeconomic background, sex, and place of residence on school attendance.

The paper has several limitations that we need to acknowledge when interpreting the results. All measures of socioeconomic background except for FSM registration are derived from household information from the Census 2001 and may have changed by the time school attendance is measured in 2007 and 2008. However, we are confident that the measures used are rather stable over time. For instance, we compared the 2001 Scottish Index of Multiple Deprivation with the measure from 2006 and found a very strong correlation (0.80). Parental class position is also more stable across the life course than family income (Goldthorpe and McKnight 2006).

There are further data limitations. First, it was not possible to determine from the data when precisely pupils were absent during the school year. Socioeconomic inequalities in school absenteeism may be more or less pronounced depending on the timing of absenteeism. Recent research has shown that missing days and months leading up to examinations have the most severe impact on children's school performance (Gottfried and Kirksey 2017). Second, we looked at two school cohorts who were in the final year of secondary schooling in 2007 and 2008. Hence, patterns of socioeconomic inequality in school absenteeism may look different in recent years. Third, compared to some US studies using administrative data (e.g., Gottfried 2014; Morrissey et al. 2014), our sample size is also rather small. However, we have the advantage that our study is representative of state schools in the whole of Scotland, whereas US studies based on administrative data are restricted to certain school districts. Fourth, the 
official School Census and examination data from Scotland do not include information on private schools. Although private schooling only represents a small fraction of schooling in Scotland (4.1 percent in 2018, Scottish Council of Independent Schools 2018), socioeconomic inequalities in school absenteeism may be different when including private schools in the sample.

Even though we have captured five different dimensions of socioeconomic background in our study, we may still underestimate the full scope of social inequality in school attendance. For instance, not all individuals considered as economically poor live in social housing or register for free school meals. While family income or measures of relative or absolute poverty correlate with our dimensions used (in particular FSM registration and social housing), they may have unique associations with school absences that are not captured by these measures. Hence, our paper establishes associations and does not assume causal relations. Adjusting for unobserved socioeconomic factors that correlate with school absences and our used dimensions may alter some of the associations found in our study.

\section{Conclusion}

Our study contributes new knowledge by showing that different dimensions of socioeconomic background are associated with adolescents' overall school attendance as well as different reasons for being absent from school. Since there is some evidence that absenteeism is detrimental to children's school performance (e.g., Gottfried 2010; Ready 2010), missing out on school is likely to be an important mechanism by which adolescents from lower socioeconomic backgrounds perform less well in school examinations than their peers from higher socioeconomic backgrounds (Morrissey et al. 2014). In other words, the differential risk of school absenteeism exacerbates socioeconomic inequalities in educational attainment. School absenteeism also has a detrimental effect on outcomes such as drug abuse (Hallfors et al. 2002) or employment opportunities (Alexander et al. 1997) and is likely to increase inequality in many life course domains. Interventions to reduce absenteeism in any form among all children and particularly 
among those from lower socioeconomic groups or areas, may, therefore, help to reduce socioeconomic inequalities in educational attainment and other life course outcomes.

Moreover, it would be worthwhile to reconsider policy decisions that are mainly driven by a single measure of socioeconomic disadvantage. A case in point is an overreliance on the Scottish Index of Multiple Deprivation (SIMD) for decision-making in Scotland. While this neighborhood socioeconomic indicator is associated with school attendance, it is by far not the only dimension that determines absences from school. Making education policy solely based on area-level information will not affect many children growing up in adverse family circumstances simply because they do not live in deprived areas. Policy-making and research may also more strongly focus on housing tenure when considering socioeconomic inequalities in life course outcomes. This is because housing tenure is strongly associated with all forms of school absenteeism independent of neighborhood and family socioeconomic circumstances.

While our study looked at different dimensions of socioeconomic background and different reasons for being absent, future research should be concerned with socioeconomic inequalities in the timing of absenteeism throughout the school year. It may be the case that children from lower socioeconomic backgrounds are more frequently missing out on school when it is most harmful to their educational careers. Future studies may also consider other measures of family socioeconomic circumstances such as family income or poverty. Whereas our study is based in Scotland and thus contributes to the literature by looking at a country context outside the US, it would be worthwhile to conduct some comparative research to see whether the relationship between socioeconomic background and school absenteeism depends on the policy context. Finally, our study was restricted to the final year of compulsory schooling. It would be illuminating to investigate the emergence of socioeconomic inequalities in school attendance throughout children's schooling. 


\section{References}

Achilles, G. M., McLaughlin, M. J., \& Croninger, R. G. (2007). Sociocultural correlates of disciplinary exclusion among students with emotional, behavioral, and learning disabilities in the SEELS national dataset. Journal of Emotional and Behavioral Disorders, 15(1), 33-45. doi:10.1177/10634266070150010401

Alexander, K. L., Entwisle, D. R., \& Dauber, S. L. (1996). Children in motion: school transfers and elementary school performance. The Journal of Education, 90(1), 3-12. doi:10.1080/00220671.1996.9944438

Alexander, K. L., Entwisle, D. R., \& Horsey, C. S. (1997). From first grade forward: Early foundations of high school dropout. Sociology of Education, 70, 97-107. doi:10.2307/2673158

Alexander, K. L., Entwisle, D. R., \& Kabbani, N. S. (2001). The dropout process in life course perspective: Early risk factors at home and school. Teachers College Record, 103, 760-822. doi:10.1111/0161-4681.00134

Attendance Works. (2016). Chronic absence: Our Top Pick for the ESSA School Quality or Student Success Indicator: A Policy Brief.

Attwood, G., \& Croll, P. (2006). Truancy in secondary school pupils: Prevalence, trajectories and pupil perspectives. Research Papers in Education, 21(4), 467-484. doi:10.1080/02671520600942446

Autor, D., Figlio, D., Karbownik, K., Roth, J., \& Wasserman, M. (2016). Family Disadvantage and the Gender Gap in Behavioral and Educational Outcomes. NBER Working Paper Series, 22267.

Balfanz, R., \& Byrnes, V. (2012). The Importance of Being In School: A Report on Absenteeism in the Nation's Public Schools. Baltimore, MD: Johns Hopkins University Center for Social Organization of Schools.

Balfanz, R., Herzog, L., \& Mac Iver, D. J. (2007). Preventing student disengagement and keeping students on the graduation path in urban middle-grades schools: Early identification and effective interventions. Educational Psychologist, 42(4), 223-235. doi:10.1080/00461520701621079

BBC (2019). School holiday fines: Parents hit by penalties rise by $93 \%$. https://www.bbc.co.uk/news/ukengland-47613726 Accessed 20 January 2020

Bowman-Perrott, L., Benz, M. R., Hsu, H., Kwok, O., Eisterhold, L. A., \& Zhang, D. (2011). Patterns and Predictors of Disciplinary Exclusion Over Time: An Analysis of the SEELS National Data Set. Journal of Emotional and Behavioral Disorders, 21(2), 83-96. doi:10.1177/1063426611407501

Brooks-Gunn, J., \& Duncan, G. J. (1997). The effects of poverty on children. Future of Children. doi:10.2307/1602387

Bukodi, E., \& Goldthorpe, J. H. (2013). Decomposing "Social Origins": The Effects of Parents' Class, Status and Education on the Educational Attainment of Their Children. European Sociological Review, 29(5), 1024-1039. doi:10.1093/esr/jcs079

Burdick-Will, J., Stein, M. L., \& Grigg, J. (2019). Danger on the Way to School: Exposure to Violent Crime, Public Transportation, and Absenteeism. Sociological Science, 6, 118-142. doi:10.15195/v6.a5

Chen, L., Jennison, B. L., \& Yang, W. (2002). Elementary School Absenteeism and Air Pollution. Inhalation Toxicology, 12, 997-1016. doi:10.1080/08958370050164626

Clark, M. D., Petras, H., Masyn, K. E., Buckley, J. A., Ialongo, N. S., \& Kellam, S. (2003). Who's Most at Risk for School Removal and Later Juvenile Delinquency? Multilevel Discrete-Time Survival Analysis of Individual- and Context-Level Influences. Journal of Educational Psychology, 103(1), 223-237. doi:10.1037/a0021545

Classi, P., Milton, D., Ward, S., Sarsour, K., \& Johnston, J. (2012). Social and emotional difficulties in children with ADHD and the impact on school attendance and healthcare utilization. Child \& Adolescent Psychiatry \& Mental Health, 6(1), 33. doi:10.1186/1753-2000-6-33

Codiroli Mcmaster, N., \& Cook, R. (2018). The contribution of intersectionality to quantitative research into educational inequalities. Review of Education, 55-59. doi:10.1002/rev3.3116

Corville-Smith, J., Ryan, B. A., Adams, G. R., \& Dalicandro, T. (1998). Distinguishing absentee 
students from regular attenders: The combined influence of personal, family, and school factors. Journal of Youth and Adolescence, 27(5), 629-640.

Currie, J., Hanushek, E. A., Kahn, E. M., Neidell, M., \& Rivkin, S. G. (2009). Does Pollution Increase School Absences? Review of Economics and Statistics, 91(4), 682-694. doi:10.1162/rest.91.4.682

Duong, M., Mora-Plazas, M., Mar, C., \& Villamor, E. (2015). Vitamin B-12 Deficiency in Children Is Associated with Grade Repetition and School Absenteeism, Independent of Folate, Iron, Zinc, or Vitamin A Status Biomarkers. Journal of Nutrition, 145(7), 1541-1548. doi:10.3945/jn.115.211391

Durán-Narucki, V. (2008). School building condition, school attendance, and academic achievement in New York City public schools: A mediation model. Journal of Environmental Psychology, 28(3), 278-286. doi:10.1016/j.jenvp.2008.02.008

Echeverría, S. E., Vélez-valle, E., Janevic, T., \& Prystowsky, A. (2014). The Role of Poverty Status and Obesity on School Attendance in the United States. Journal of Adolescent Health, 55(3), 402-407. doi:10.1016/j.jadohealth.2014.03.012

Engberg, J., \& Morral, A. R. (2006). Reducing substance use improves adolescents' school attendance. Addiction, 101, 1741-1751. doi:10.1111/j.1360-0443.2006.01544.x

Epstein, J. L., \& Sheldon, S. B. (2002). Present and accounted for: Improving student attendance through family and community involvement. Journal of Educational Research, 95(5), 308-318. doi:10.1080/00220670209596604

Gennetian, L. A., Rodrigues, C., Hill, H. D., \& Morris, P. A. (2018). Stability of income and school attendance among NYC students of low- income families. Economics of Education Review, 63, 2030. doi:10.1016/j.econedurev.2018.01.003

Gilliland, F. D., Berhane, K., Rappaport, E. B., Thomas, D. C., Avol, E., Gauderman, W. J., et al. (2001). The effects of ambient air pollution on school absenteeism due to respiratory illnesses. Epidemiology, 12(1), 43-54. doi:10.1097/00001648-200101000-00009

Goldthorpe, J. H., \& McKnight, A. (2006). The Economic Basis of Social Class. In S. L. Morgan, D. B. Grusky, \& G. S. Fields (Eds.), Mobility and Inequality: Frontiers of Research in Sociology and Economics (pp. 109-136). Stanford: Stanford University Press.

Goodman, E., \& Huang, B. (2015). Socioeconomic Status, Depressive Symptoms, and Adolescent Substance Use. Arch Pediatr Adolesc Med., 156(5), 448-453. doi:10.1001/archpedi.156.5.448

Gottfried, M. A. (2009). Excused Versus Unexcused: How Student Absences in Elementary School Affect Academic Achievement. Educational Evaluation and Policy Analysis, 31(4), 392-415. doi:10.3102/0162373709342467

Gottfried, M. A. (2010). Evaluating the Relationship Between Student Attendance and Achievement in Urban Elementary and Middle Schools: An Instrumental Variables Approach. American Educational Research Jounal, 47(2), 434-465. doi:10.3102/0002831209350494

Gottfried, M. A. (2014). Can Neighbor Attributes Predict School Absences? Urban Education, 49(2), 216-250. doi:10.1177/0042085913475634

Gottfried, M. A. (2017). Linking Getting to School With Going to School. Educational Evaluation and Policy Analysis, 39(4), 571-592. doi:10.3102/0162373717699472

Gottfried, M. A., \& Gee, K. A. (2017). Identifying the Determinants of Chronic Absenteeism: A Bioecological Systems Approach. Teachers College Record, 119, 1-34.

Gottfried, M. A., \& Kirksey, J. J. (2017). "When" students miss school: The role of timing of absenteeism on students' test performance. Educational Researcher, 46(3), 119-130. https://doi.org/10.3102/0013189X17703945

Gottfried, M. A., \& Hutt, E. (2019). Absent from School: Understanding and Addressing Student Absenteeism. Cambridge, MA: Havard University Press.

Gubbels, J., van der Put, C. E., \& Assink, M. (2019). Risk Factors for School Absenteeism and Dropout: A Meta-Analytic Review. Journal of Youth and Adolescence, 48, 1637-1667. doi:10.1007/s10964019-01072-5

Hallfors, D., Vevea, J. L., Iritani, B., Cho, H. S., Khatapoush, S., \& Saxe, L. (2002). Truancy, grade point average, and sexual activity: A meta-analysis of risk indicators for youth substance use. Journal of 
School Health, 72(5), 205-211. doi:10.1111/j.1746-1561.2002.tb06548.x

Hemphill, S. A., Plenty, S. M., Herrenkohl, T. I., Toumbourou, J. W., \& Catalano, R. F. (2014). Student and school factors associated with school suspension: A multilevel analysis of students in Victoria, Australia and Washington State, United States. Children and Youth Services Review, 36, 187-194. doi:10.1016/j.childyouth.2013.11.022

Hobbs, G., \& Vignoles, A. (2010). Is children's free school meal "eligibility" a good proxy for family income? British Educational Research Journal, 36(4), 673-690. doi:10.1080/01411920903083111

Iannelli, C., \& Duta, A. (2018). Inequalities in school leavers' labour market outcomes: do school subject choices matter? Oxford Review of Education, 44(1), 56-74. doi:10.1080/03054985.2018.1409970

Ingul, J. M., Klo, C. A., Silverman, W. K., \& Hans, M. (2012). Adolescent school absenteeism: modelling social and individual risk factors. Child and Adolescent Mental Health, 17(2), 93-100. doi:10.1111/j.1475-3588.2011.00615.x

Jenkins, S. P. (2011). Changing fortunes: Income mobility and poverty dynamics in Britain. Oxford, UK: Oxford University Press.

Jeynes, W. H. (2005). A meta-analysis of the relation of parental involvement to urban elementary school student academic achievement. Urban Education, 40(3), 237-269. doi:10.1177/0042085905274540

Jordan, W. P., \& Miller, R. (2017). Who's in: Chronic absenteeism under the Every Student Succeeds Act. Washington, DC: FutureEd at Georgetown University.

Kearney, C. A. (2009). School absenteeism and school refusal behavior in youth: A contemporary review. Clinical Psychology Review, 28(3), 451-471. https://doi.org/10.1016/j.cpr.2007.07.012

Mazza, J. R. S. E., Lambert, J., Zunzunegui, M. V., Tremblay, R. E., Boivin, M., \& Côté, S. M. (2017). Early adolescence behavior problems and timing of poverty during childhood: A comparison of lifecourse models. Social Science and Medicine, 177, 35-42. doi:10.1016/j.socscimed.2017.01.039

McKendrick, J. H., Bouse, D., Connell, D., Ferguson J., Graham, K., Marshall, K., McRobert, S., McGee, R., Swan, R., Tomassi, L. \& Vasilev, V. (2019). Are pupils being served? A secondary review of the sector's evidence base on school meal provision at lunchtime in Scotland. Scottish Poverty and Inequality Research Unit, Glasgow Caledonian University.

McVie, S. (2006). Truancy, exclusion and offending: Evidence from the Edinburgh Study. Presentation to Social Justice Scrutiny Panel, December 2006.

Mood, C. (2010). Logistic Regression: Why We Cannot Do What We Think We Can Do, and What We Can Do About It. European Sociological Review, 26(1), 67-82. doi:10.1093/esr/jcp006

Moonie, S. A., Sterling, D. A., Figgs, L., \& Castro, M. (2006). Asthma status and severity affects missed school days. Journal of School Health, 76(1), 18-24. doi:10.1111/j.1746-1561.2006.00062.x

Morrissey, T. W., Hutchison, L., \& Winsler, A. (2014). Family income, school attendance, and academic achievement in elementary school. Developmental Psychology, 50(3), 741-753. doi:10.1037/a0033848

Mueller, D., \& Stoddard, C. (2006). Dealing With Chronic Absenteeism and Its Related Consequences: The Process and Short-Term Effects of a Diversionary Juvenile Court Intervention. Journal of Education for Students Placed at Risk (JESPAR), 11, 199-219. doi:10.1207/s15327671espr1102_5

Newman, S. J. (2008). Does housing matter for poor families? A critical summary of research and issues still to be resolved. Journal of Policy Analysis and Management, 27(4), 895-925. doi:10.1002/pam.20381

Nolan, J. R., Cole, T., Wroughton, J., Clayton-Code, K. P., \& Riffe, H. A. (2013). Assessment of Risk Factors for Truancy of Children in Grades K-12 Using Survival Analysis. Journal of At-Risk Issues, 17(2), 23-30.

Ou, S. R., \& Reynolds, A. J. (2008). Predictors of Educational Attainment in the Chicago Longitudinal Study. School Psychology Quarterly, 23, 199-229. doi:10.1037/1045-3830.23.2.199

Paget, A., Parker, C., Logan, S., \& Ford, T. (2017). Which children and young people are excluded from school? Findings from a large British birth cohort study, the Avon Longitudinal Study of Parents and Children (ALSPAC). Child: Care, Health and Development, 44, 285-296. doi:10.1111/cch.12525 
Papke, L. E., \& Wooldridge, J. M. (1996). Econometric methods for fractional response variables with an application to 401 (K) plan participation rates. Journal of Applied Econometrics, 11(February), 619632.

doi:10.1002/(SICI)1099-1255(199611)11:6<619::AID-JAE418>3.0.CO;2-1

Plan International UK. (2017). Plan International UK's Research on Period Poverty and Stigma. https://plan-uk.org/media-centre/plan-international-uks-research-on-period-poverty-and-stigma.

Accessed 18 September 2019

Ready, D. D. (2010). Socioeconomic Disadvantage , School Attendance, and Early Cognitive Development: The Differential Effects of School Exposure. Sociology of Education, 83(4), 271286. doi: $10.1177 / 0038040710383520$

Reid, K. (2005). The causes, views and traits of school absenteeism and truancy. Research in Education, 74, 59-82. doi:10.7227/RIE.74.6

Rhoad-Drogalis, A., \& Justice, L. M. (2018). Absenteeism in Appalachian preschool classrooms and children's academic. Journal of Applied Developmental Psychology, 58(July), 1-8. doi:10.1016/j.appdev.2018.07.004

Rodríguez, L. F., \& Conchas, G. Q. (2009). Preventing truancy and dropout among urban middle school youth: Understanding community-based action from the student's perspective. Education and Urban Society, 41(2), 216-247. doi:10.1177/0013124508325681

Rumberger, R. W. (1995). Dropping Out of Middle School: A Multilevel Analysis of Students and Schools. American Educational Research Journal, 32, 583-625. doi:10.3102/00028312032003583

Schenck-Fontaine, A., \& Panico, L. (2019). Many Kinds of Poverty: Three Dimensions of Economic Hardship, Their Combinations, and Children's Behavior Problems. Demography, in press. doi:10.1007/s13524-019-00833-y

Scottish Council of Independent Schools. (2018). Annual Census. http://www.scis.org.uk/facts-andfigures/ Accessed 13 January 2020.

Scottish Government. (2010). Summary Statistics for Schools in Scotland, No. 1.

Scottish Government. (2017). Summary Statistics for Schools in Scotland, No. 8.

Scottish Government. (2018). Rural Scotland: Key Facts 2018.

Skola, E. P., \& Williamson, K. (2012). The Truancy Intervention Project: Our Tips for Success. Family Court Review, 50, 405-412. https://doi.org/10.1111/j.1744-1617.2012.01456.x

SLS-DSU. (n.d.). Step-by-step guide to accessing SLS data. https://sls.lscs.ac.uk/guides-resources/stepbystep-guide-to-accessing-sls-data-1/ Accessed 13 January 2020

Stein, M. L., \& Grigg, J. A. (2019). Missing Bus, Missing School: Establishing the Relationship Between Public Transit Use and Student Absenteeism. American Educational Research Journal, 56(5), 1834-1860. doi:10.3102/0002831219833917

Stempel, H., Cox-Martin, M., Bronsert, M., Dickinson, L. M., \& Allison, M. A. (2017). Chronic School Absenteeism and the Role of Adverse Childhood Experiences. Academic Pediatrics, 17(8), 837843. doi:10.1016/j.acap.2017.09.013

Strand S, Fletcher J (2014) A quantitative longitudinal analysis of exclusions from English secondary schools. Oxford: University of Oxford.

Sullivan, A. L., Klingbeil, D. A., \& Nortnan, E. R. Van. (2013). Beyond Behavior: Multilevel Analysis of the Influence of Sociodemographics and School Characteristics on Students' Risk of Suspension. School Psychology Review, 42(1), 99-114.

Tunstall, R., Bevan, M., Bradshaw, J., Croucher, K., Duffy, S., Hunter, C., et al. (2013). The Links Between Housing and Poverty: An Evidence Review. Joseph Rowntree Foundation.

Tyler, K. A., \& Bersani, B. E. (2008). A longitudinal study of early adolescent precursors to running away. Journal of Early Adolescence, 28(2), 230-251. doi:10.1177/0272431607313592

UK Department of Education. (2019). Timpson Review of School Exclusion. https://assets.publishing.service.gov.uk/government/uploads/system/uploads/attachment_data/file/80 7862/Timpson_review.pdf. Accessed 13 January 2020 
WHO/UNICEF. (2012). Report of the Second Consultation on Post-2015 Monitoring Report of a Consultation. The Hague. World Health Organization/United Nations International Children's Emergency Fund.

Wolf, K. C., \& Kupchik, A. (2017). School Suspensions and Adverse Experiences in Adulthood. Justice Quarterly, 34(3), 407-430. https://doi.org/10.1080/07418825.2016.1168475

Zhang D., Katsiyannis, A., Barrett, D. E., \& Willson, V. (2007). Truancy Offenders in the Juvenile Justice System examinations of first and second referrals. Remedial and Special Education, 28(4), 244-256. doi:10.1177/07419325070280040401 


\section{Supplementary Material}

Table S1. Correlation matrix for dimensions of socio-economic background $(n=4620)$

\begin{tabular}{lcclll}
\hline & Parental educ. & Parental class & $\begin{array}{l}\text { Free School } \\
\text { Meal Reg. }\end{array}$ & $\begin{array}{l}\text { Housing } \\
\text { tenure }\end{array}$ & SIMD \\
Parental educ. & - & & & \\
Parental class & 0.33 & - & & \\
Free School Meal Reg. & 0.30 & 0.30 & - & - \\
Housing Tenure & 0.44 & 0.49 & 0.33 & 0.48 & - \\
SIMD & 0.22 & 0.23 & 0.24 & \\
\hline
\end{tabular}

Source. Scottish Longitudinal Study, own calculations. Note: Correlation coefficients based on Cramer's V. 
Table S2. Summary of fractional logit models predicting overall absenteeism among pupils in their final year of secondary schooling

\begin{tabular}{|c|c|c|c|c|c|}
\hline & Overall & Male & Female & Urban & Rural \\
\hline \multicolumn{6}{|l|}{ Parental education (Ref. First degree) } \\
\hline \multirow[t]{2}{*}{ College below degree } & 0.012 & 0.011 & 0.013 & 0.011 & 0.019 \\
\hline & $(0.007)$ & $(0.009)$ & $(0.009)$ & $(0.008)$ & $(0.012)$ \\
\hline \multirow[t]{2}{*}{ Upper secondary qualification } & 0.007 & 0.006 & 0.008 & 0.009 & 0.001 \\
\hline & $(0.006)$ & $(0.008)$ & $(0.008)$ & $(0.006)$ & $(0.011)$ \\
\hline \multirow[t]{2}{*}{ Lower secondary qualification } & $0.022^{* * *}$ & $0.016^{*}$ & $0.029^{* * *}$ & $0.023^{* *}$ & $0.023^{*}$ \\
\hline & $(0.006)$ & $(0.007)$ & $(0.008)$ & $(0.007)$ & $(0.010)$ \\
\hline \multirow[t]{2}{*}{ No qualifications } & $0.041^{* * *}$ & $0.041^{* * *}$ & $0.041^{* *}$ & $0.041^{* * *}$ & $0.042^{*}$ \\
\hline & $(0.008)$ & $(0.010)$ & $(0.012)$ & $(0.009)$ & $(0.019)$ \\
\hline \multicolumn{6}{|l|}{$\begin{array}{l}\text { Parental class (Ref. Higher managerial } \\
\text { and professional occupations) }\end{array}$} \\
\hline \multirow[t]{2}{*}{ Intermediate occupations } & 0.003 & 0.000 & 0.005 & -0.000 & 0.013 \\
\hline & $(0.006)$ & $(0.007)$ & $(0.008)$ & $(0.006)$ & $(0.011)$ \\
\hline \multirow[t]{2}{*}{ Small employers and own account workers } & $0.019^{*}$ & $0.024^{*}$ & 0.014 & 0.016 & 0.025 \\
\hline & $(0.008)$ & $(0.012)$ & $(0.011)$ & $(0.009)$ & $(0.013)$ \\
\hline \multirow{2}{*}{$\begin{array}{l}\text { Lower supervisory and technical } \\
\text { occupations }\end{array}$} & $0.015^{*}$ & 0.010 & 0.022 & 0.0137 & 0.020 \\
\hline & $(0.007)$ & $(0.008)$ & $(0.011)$ & $(0.008)$ & $(0.012)$ \\
\hline \multirow[t]{2}{*}{ Semi-routine and routine occupations } & $0.020^{* *}$ & $0.020^{*}$ & $0.021^{*}$ & $0.048^{* * *}$ & 0.016 \\
\hline & $(0.006)$ & $(0.009)$ & $(0.010)$ & $(0.005)$ & $(0.010)$ \\
\hline \multicolumn{6}{|l|}{$\begin{array}{l}\text { Free school meal registration (Ref. Not } \\
\text { registered) }\end{array}$} \\
\hline \multirow[t]{2}{*}{ Registered } & $0.037^{* * *}$ & $0.034^{* *}$ & $0.038^{* *}$ & $0.035^{* * *}$ & $0.047^{* *}$ \\
\hline & $(0.008)$ & $(0.011)$ & $(0.011)$ & $(0.009)$ & $(0.014)$ \\
\hline \multicolumn{6}{|l|}{$\begin{array}{l}\text { Housing tenure (Ref. Owned/Private } \\
\text { rented) }\end{array}$} \\
\hline \multirow[t]{2}{*}{ Social rented } & $0.043^{* * *}$ & $0.046^{* * *}$ & $0.038^{* * *}$ & $0.048^{* * *}$ & $0.024^{* *}$ \\
\hline & $(0.005)$ & $(0.007)$ & $(0.007)$ & $(0.005)$ & $(0.010)$ \\
\hline $\begin{array}{l}\text { Scottish Index of Multiple Deprivation } \\
\text { (SIMD) (Ref. SIMD 5=least deprived) }\end{array}$ & & & & & \\
\hline
\end{tabular}




\begin{tabular}{|c|c|c|c|c|c|}
\hline \multirow[t]{2}{*}{ SIMD4 } & 0.005 & 0.009 & 0.001 & 0.005 & 0.005 \\
\hline & $(0.006)$ & $(0.008)$ & $(0.008)$ & $(0.007)$ & $(0.011)$ \\
\hline \multirow[t]{2}{*}{ SIMD3 } & $0.015^{* *}$ & $0.024^{* *}$ & 0.005 & $0.015^{*}$ & 0.015 \\
\hline & $(0.006)$ & $(0.007)$ & $(0.009)$ & $(0.007)$ & $(0.011)$ \\
\hline \multirow[t]{2}{*}{ SIMD2 } & $0.024^{* * *}$ & $0.025^{* *}$ & $0.023^{*}$ & $0.023^{* *}$ & $0.030^{*}$ \\
\hline & $(0.006)$ & $(0.008)$ & $(0.009)$ & $(0.007)$ & $(0.015)$ \\
\hline \multirow[t]{2}{*}{ SIMD1=most deprived } & $0.029^{* * *}$ & $0.037^{* * *}$ & 0.018 & $0.028^{* * * *}$ & 0.025 \\
\hline & $(0.007)$ & $(0.008)$ & $(0.010)$ & $(0.007)$ & $(0.020)$ \\
\hline \multicolumn{6}{|l|}{ Sex (Ref. Male) } \\
\hline \multirow[t]{2}{*}{ Female } & $0.011^{* *}$ & & & $0.010^{*}$ & $0.013^{*}$ \\
\hline & $(0.004)$ & & & $(0.007)$ & $(0.006)$ \\
\hline \multicolumn{6}{|l|}{ Place of residence (Ref. Urban) } \\
\hline \multirow[t]{2}{*}{ Rural } & $-0.022^{* * * *}$ & $-0.025^{* *}$ & $-0.020^{* *}$ & & \\
\hline & $(0.005)$ & $(0.006)$ & $(0.006)$ & & \\
\hline \multicolumn{6}{|l|}{ Ethnicity (Ref. “White”) } \\
\hline \multirow[t]{2}{*}{ "Other ethnic background" } & -0.002 & -0.013 & 0.014 & -0.002 & 0.004 \\
\hline & $(0.011)$ & $(0.014)$ & $(0.016)$ & $(0.013)$ & $(0.012)$ \\
\hline \multirow[t]{2}{*}{ Child's age at start of secondary schooling } & $0.013^{*}$ & -0.002 & $0.029^{* *}$ & 0.010 & 0.023 \\
\hline & $(0.006)$ & $(0.009)$ & $(0.009)$ & $(0.007)$ & $(0.013)$ \\
\hline \multirow[t]{2}{*}{ Mother's age at birth } & -0.000 & 0.000 & -0.001 & -0.000 & 0.000 \\
\hline & $(0.000)$ & $(0.001)$ & $(0.001)$ & $(0.000)$ & 0.001 \\
\hline \multicolumn{6}{|l|}{ School cohort (Ref. 2008) } \\
\hline \multirow[t]{2}{*}{2007} & 0.001 & -0.002 & 0.004 & 0.003 & -0.005 \\
\hline & $(0.004)$ & $(0.005)$ & $(0.005)$ & $(0.004)$ & $(0.007)$ \\
\hline $\mathrm{N}$ & 4620 & 2429 & 2191 & 3585 & 1035 \\
\hline
\end{tabular}

Source. Scottish Longitudinal Study, own calculations. Note. ${ }^{*} p<.05,{ }^{* *} p<.01,{ }^{* * *} p<.001$. Estimates shown as Average Marginal Effects (AMEs). Cluster-robust standard errors in parentheses. 
Table S3. Summary of fractional logit models predicting sickness-related absenteeism among pupils in their final year of secondary schooling

\begin{tabular}{|c|c|c|c|c|c|}
\hline & Overall & Male & Female & Urban & Rural \\
\hline \multicolumn{6}{|l|}{ Parental education (Ref. First degree) } \\
\hline \multirow[t]{2}{*}{ College below degree } & 0.006 & 0.007 & 0.004 & 0.006 & 0.008 \\
\hline & $(0.003)$ & $(0.005)$ & $(0.005)$ & $(0.004)$ & $(0.007)$ \\
\hline \multirow[t]{2}{*}{ Upper secondary qualification } & 0.005 & 0.006 & 0.004 & $0.007^{*}$ & 0.002 \\
\hline & $(0.003)$ & $(0.003)$ & $(0.004)$ & $(0.003)$ & $(0.005)$ \\
\hline \multirow[t]{2}{*}{ Lower secondary qualification } & $0.013^{* * *}$ & $0.010^{* *}$ & $0.017^{* * * *}$ & $0.014^{* * * *}$ & $0.012^{*}$ \\
\hline & $(0.003)$ & $(0.003)$ & $(0.005)$ & $(0.003)$ & $(0.005)$ \\
\hline \multirow[t]{2}{*}{ No qualifications } & $0.015^{* *}$ & $0.014^{* *}$ & $0.016^{*}$ & $0.015^{* *}$ & 0.018 \\
\hline & $(0.005)$ & $(0.006)$ & $(0.007)$ & $(0.005)$ & $(0.010)$ \\
\hline \multicolumn{6}{|l|}{$\begin{array}{l}\text { Parental class (Ref. Higher managerial and } \\
\text { professional occupations) }\end{array}$} \\
\hline \multirow[t]{2}{*}{ Intermediate occupations } & $0.006^{*}$ & 0.004 & 0.008 & 0.006 & 0.005 \\
\hline & $(0.003)$ & $(0.004)$ & $(0.005)$ & $(0.003)$ & $(0.006)$ \\
\hline \multirow[t]{2}{*}{ Small employers and own account workers } & $0.010 *$ & $0.019^{* *}$ & -0.002 & 0.008 & $0.014^{*}$ \\
\hline & $(0.004)$ & $(0.006)$ & $(0.006)$ & $(0.005)$ & $(0.007)$ \\
\hline \multirow[t]{2}{*}{ Lower supervisory and technical occupations } & 0.007 & 0.004 & 0.010 & 0.006 & 0.013 \\
\hline & $(0.004)$ & $(0.004)$ & $(0.006)$ & $(0.004)$ & $(0.008)$ \\
\hline \multirow[t]{2}{*}{ Semi-routine and routine occupations } & 0.003 & 0.006 & -0.000 & 0.003 & 0.003 \\
\hline & $(0.003)$ & $(0.004)$ & $(0.005)$ & $(0.004)$ & $(0.005)$ \\
\hline \multicolumn{6}{|l|}{$\begin{array}{l}\text { Free school meal registration (Ref. Not } \\
\text { registered) }\end{array}$} \\
\hline \multirow[t]{2}{*}{ Registered } & $0.011^{*}$ & 0.006 & $0.015^{*}$ & $0.010^{*}$ & 0.017 \\
\hline & $(0.004)$ & $(0.006)$ & $(0.006)$ & $(0.005)$ & $(0.009)$ \\
\hline \multicolumn{6}{|l|}{ Housing tenure (Ref. Owned/Private rented) } \\
\hline \multirow[t]{2}{*}{ Social rented } & $0.017^{* * *}$ & $0.016^{* * *}$ & $0.018^{* * *}$ & $0.020^{* * *}$ & 0.007 \\
\hline & $(0.003)$ & $(0.004)$ & $(0.004)$ & $(0.004)$ & $(0.005)$ \\
\hline \multicolumn{6}{|l|}{$\begin{array}{l}\text { Scottish Index of Multiple Deprivation } \\
\text { (SIMD) (Ref. SIMD 5=least deprived) }\end{array}$} \\
\hline \multirow[t]{2}{*}{ SIMD4 } & -0.001 & -0.002 & -0.000 & 0.000 & -0.005 \\
\hline & $(0.003)$ & $(0.004)$ & $(0.004)$ & $(0.003)$ & $(0.006)$ \\
\hline \multirow[t]{2}{*}{ SIMD3 } & 0.003 & 0.003 & 0.004 & -0.000 & 0.005 \\
\hline & $(0.003)$ & $(0.003)$ & $(0.005)$ & $(0.004)$ & $(0.006)$ \\
\hline
\end{tabular}




\begin{tabular}{|c|c|c|c|c|c|}
\hline \multirow[t]{2}{*}{ SIMD2 } & $0.008^{*}$ & 0.006 & 0.010 & $0.009^{*}$ & -0.004 \\
\hline & $(0.003)$ & $(0.004)$ & $(0.005)$ & $(0.004)$ & $(0.008)$ \\
\hline \multirow[t]{2}{*}{ SIMD1=most deprived } & -0.000 & 0.004 & -0.006 & -0.003 & 0.011 \\
\hline & $(0.005)$ & $(0.006)$ & $(0.006)$ & $(0.005)$ & $(0.013)$ \\
\hline \multicolumn{6}{|l|}{ Sex (Ref. Male) } \\
\hline \multirow[t]{2}{*}{ Female } & $0.011^{* * * *}$ & & & $0.011^{* * *}$ & $0.013^{* * *}$ \\
\hline & $(0.002)$ & & & $(0.002)$ & $(0.004)$ \\
\hline Place of residence (Ref. Urban) & 0.000 & -0.000 & 0.001 & & \\
\hline Rural & $(0.003)$ & $(0.003)$ & $(0.004)$ & & \\
\hline \multicolumn{6}{|l|}{ Ethnicity (Ref. “White”) } \\
\hline \multirow[t]{2}{*}{ "Other ethnic background" } & -0.008 & $-0.015^{* *}$ & 0.004 & -0.011 & 0.020 \\
\hline & $(0.005)$ & $(0.005)$ & $(0.008)$ & $(0.006)$ & $(0.010)$ \\
\hline \multirow[t]{2}{*}{ Child's age at start of secondary schooling } & $0.011^{*}$ & 0.006 & $0.018^{* *}$ & $0.010^{*}$ & $0.018^{*}$ \\
\hline & $(0.004)$ & $(0.004)$ & $(0.006)$ & $(0.004)$ & $(0.007)$ \\
\hline \multirow[t]{2}{*}{ Mother's age at birth } & 0.000 & 0.000 & -0.000 & -0.000 & 0.000 \\
\hline & $(0.000)$ & $(0.000)$ & $(0.000)$ & $(0.000)$ & 0.000 \\
\hline \multicolumn{6}{|l|}{ School cohort (Ref. 2008) } \\
\hline \multirow[t]{2}{*}{2007} & -0.002 & -0.001 & -0.003 & -0.002 & 0.001 \\
\hline & $(0.002)$ & $(0.003)$ & $(0.003)$ & $(0.002)$ & $(0.004)$ \\
\hline $\mathrm{N}$ & 4620 & 2429 & 2191 & 3585 & 1035 \\
\hline
\end{tabular}

Source. Scottish Longitudinal Study, own calculations. Note. ${ }^{*} p<.05,{ }^{* *} p<.01,{ }^{* * *} p<.001$. Estimates shown as Average Marginal Effects (AMEs). Cluster-robust standard errors in parentheses. 
Table S4. Summary of logistic regressions predicting absences due to family holidays among pupils in their final year of secondary schooling

\begin{tabular}{|c|c|c|c|c|c|}
\hline & Overall & Male & Female & Urban & Rural \\
\hline \multicolumn{6}{|l|}{ Parental education (Ref. First degree) } \\
\hline \multirow[t]{2}{*}{ College below degree } & -0.002 & -0.019 & 0.016 & -0.012 & 0.042 \\
\hline & $(0.019)$ & $(0.026)$ & $(0.027)$ & $(0.021)$ & $(0.044)$ \\
\hline \multirow[t]{2}{*}{ Upper secondary qualification } & 0.016 & -0.018 & $0.056^{*}$ & 0.012 & 0.036 \\
\hline & $(0.016)$ & $(0.026)$ & $(0.023)$ & $(0.018)$ & $(0.035)$ \\
\hline \multirow[t]{2}{*}{ Lower secondary qualification } & 0.025 & -0.001 & $0.053^{*}$ & 0.023 & 0.033 \\
\hline & $(0.017)$ & $(0.024)$ & $(0.025)$ & $(0.019)$ & $(0.035)$ \\
\hline \multirow[t]{2}{*}{ No qualifications } & -0.020 & $-0.052^{*}$ & 0.020 & -0.022 & -0.001 \\
\hline & $(0.020)$ & $(0.026)$ & $(0.031)$ & $(0.022)$ & $(0.051)$ \\
\hline \multicolumn{6}{|l|}{$\begin{array}{l}\text { Parental class (Ref. Higher managerial } \\
\text { and professional occupations) }\end{array}$} \\
\hline \multirow[t]{2}{*}{ Intermediate occupations } & -0.001 & -0.010 & -0.009 & -0.002 & -0.035 \\
\hline & $(0.016)$ & $(0.023)$ & $(0.025)$ & $(0.018)$ & $(0.033)$ \\
\hline \multirow{2}{*}{$\begin{array}{l}\text { Small employers and own account } \\
\text { workers }\end{array}$} & -0.011 & 0.022 & -0.049 & -0.026 & 0.020 \\
\hline & $(0.022)$ & $(0.029)$ & $(0.031)$ & $(0.026)$ & $(0.043)$ \\
\hline \multirow{2}{*}{$\begin{array}{l}\text { Lower supervisory and technical } \\
\text { occupations }\end{array}$} & -0.007 & 0.006 & -0.023 & -0.026 & 0.052 \\
\hline & $(0.020)$ & $(0.028)$ & $(0.027)$ & $(0.020)$ & $(0.044)$ \\
\hline \multirow[t]{2}{*}{ Semi-routine and routine occupations } & -0.028 & -0.029 & -0.030 & -0.018 & -0.067 \\
\hline & $(0.018)$ & $(0.023)$ & $(0.026)$ & $(0.020)$ & $(0.034)$ \\
\hline \multicolumn{6}{|l|}{$\begin{array}{l}\text { Free school meal registration (Ref. Not } \\
\text { registered) }\end{array}$} \\
\hline \multirow[t]{2}{*}{ Registered } & $-0.046^{*}$ & -0.032 & $-0.063^{* *}$ & $-0.054^{* *}$ & 0.004 \\
\hline & $(0.018)$ & $(0.026)$ & $(0.024)$ & $(0.018)$ & $(0.062)$ \\
\hline \multicolumn{6}{|l|}{$\begin{array}{l}\text { Housing tenure (Ref. Owned/Private } \\
\text { rented }\end{array}$} \\
\hline \multirow[t]{2}{*}{ Social rented } & -0.013 & 0.003 & -0.025 & -0.011 & -0.023 \\
\hline & $(0.015)$ & $(0.022)$ & $(0.022)$ & $(0.017)$ & $(0.032)$ \\
\hline \multicolumn{6}{|l|}{$\begin{array}{l}\text { Scottish Index of Multiple Deprivation } \\
(\text { SIMD) (Ref. SIMD 5=least deprived) }\end{array}$} \\
\hline SIMD4 & 0.013 & -0.016 & $0.048^{*}$ & 0.015 & 0.019 \\
\hline
\end{tabular}




\begin{tabular}{|c|c|c|c|c|c|}
\hline & $(0.016)$ & $(0.022)$ & $(0.022)$ & $(0.018)$ & $(0.034)$ \\
\hline \multirow[t]{2}{*}{ SIMD3 } & 0.000 & -0.015 & 0.019 & -0.011 & 0.024 \\
\hline & $(0.017)$ & $(0.024)$ & $(0.024)$ & $(0.020)$ & $(0.035)$ \\
\hline \multirow[t]{2}{*}{ SIMD2 } & 0.012 & 0.008 & 0.019 & 0.005 & 0.030 \\
\hline & $(0.019)$ & $(0.027)$ & $(0.026)$ & $(0.021)$ & $(0.045)$ \\
\hline \multirow[t]{2}{*}{ SIMD1=most deprived } & -0.012 & -0.034 & 0.008 & -0.022 & 0.038 \\
\hline & $(0.019)$ & $(0.025)$ & $(0.029)$ & $(0.021)$ & $(0.074)$ \\
\hline \multicolumn{6}{|l|}{ Sex (Ref. Male) } \\
\hline \multirow[t]{2}{*}{ Female } & $0.025^{*}$ & & & 0.024 & 0.031 \\
\hline & $(0.011)$ & & & $(0.012)$ & $(0.022)$ \\
\hline \multicolumn{6}{|l|}{ Place of residence (Ref. Urban) } \\
\hline \multirow[t]{2}{*}{ Rural } & 0.001 & -0.002 & 0.002 & & \\
\hline & $(0.015)$ & $(0.019)$ & $(0.021)$ & & \\
\hline \multicolumn{6}{|l|}{ Ethnicity (Ref. "White") } \\
\hline \multirow[t]{2}{*}{ "Other ethnic background" } & 0.001 & -0.037 & 0.063 & -0.018 & 0.122 \\
\hline & $(0.031)$ & $(0.032)$ & $(0.060)$ & $(0.031)$ & $(0.107)$ \\
\hline \multirow[t]{2}{*}{ Child's age at start of secondary schooling } & -0.007 & -0.045 & 0.035 & 0.002 & -0.032 \\
\hline & $(0.019)$ & $(0.025)$ & $(0.026)$ & $(0.020)$ & $(0.044)$ \\
\hline \multirow[t]{2}{*}{ Mother's age at birth } & -0.002 & -0.001 & -0.002 & -0.002 & 0.001 \\
\hline & $(0.001)$ & $(0.002)$ & $(0.002)$ & $(0.001)$ & $(0.003)$ \\
\hline School cohort (Ref. 2008) & $0.022^{*}$ & 0.020 & 0.025 & 0.024 & 0.022 \\
\hline 2007 & $(0.011)$ & $(0.014)$ & $(0.016)$ & $(0.012)$ & $(0.021)$ \\
\hline $\mathrm{N}$ & 4620 & 2429 & 2191 & 3585 & 1035 \\
\hline
\end{tabular}

Source. Scottish Longitudinal Study, own calculations. Note. ${ }^{*} p<.05,{ }^{* *} p<.01,{ }^{* * *} p<.001$. Estimates shown as Average Marginal Effects (AMEs). Cluster-robust standard errors in parentheses 
Table S5. Summary of fractional logit models predicting truancy among pupils in their final year of secondary schooling

\begin{tabular}{|c|c|c|c|c|c|}
\hline & Overall & Male & Female & Urban & Rural \\
\hline \multicolumn{6}{|l|}{ Parental education (Ref. First degree) } \\
\hline \multirow[t]{2}{*}{ College below degree } & -0.001 & -0.002 & 0.001 & -0.002 & 0.004 \\
\hline & $(0.003)$ & $(0.003)$ & $(0.004)$ & $(0.003)$ & $(0.004)$ \\
\hline \multirow[t]{2}{*}{ Upper secondary qualification } & 0.000 & 0.001 & -0.001 & 0.000 & -0.000 \\
\hline & $(0.003)$ & $(0.003)$ & $(0.004)$ & $(0.003)$ & $(0.003)$ \\
\hline \multirow[t]{2}{*}{ Lower secondary qualification } & 0.004 & 0.004 & 0.005 & 0.004 & 0.004 \\
\hline & $(0.003)$ & $(0.003)$ & $(0.005)$ & $(0.004)$ & $(0.004)$ \\
\hline \multirow[t]{2}{*}{ No qualifications } & $0.009^{*}$ & $0.009^{*}$ & 0.008 & 0.009 & 0.008 \\
\hline & $(0.004)$ & $(0.004)$ & $(0.007)$ & $(0.005)$ & $(0.006)$ \\
\hline \multicolumn{6}{|l|}{$\begin{array}{l}\text { Parental class (Ref. Higher managerial } \\
\text { and professional occupations) }\end{array}$} \\
\hline \multirow[t]{2}{*}{ Intermediate occupations } & -0.003 & -0.001 & -0.004 & -0.004 & 0.002 \\
\hline & $(0.002)$ & $(0.003)$ & $(0.003)$ & $(0.002)$ & $(0.003)$ \\
\hline \multirow[t]{2}{*}{ Small employers and own account workers } & 0.002 & 0.002 & 0.004 & 0.000 & 0.006 \\
\hline & $(0.003)$ & $(0.004)$ & $(0.004)$ & $(0.004)$ & $(0.005)$ \\
\hline \multirow{2}{*}{$\begin{array}{l}\text { Lower supervisory and technical } \\
\text { occupations }\end{array}$} & 0.003 & -0.001 & 0.008 & 0.002 & 0.005 \\
\hline & $(0.003)$ & $(0.003)$ & $(0.005)$ & $(0.003)$ & $(0.004)$ \\
\hline \multirow[t]{2}{*}{ Semi-routine and routine occupations } & $0.007^{*}$ & 0.005 & 0.010 & 0.007 & 0.006 \\
\hline & $(0.003)$ & $(0.003)$ & $(0.005)$ & $(0.004)$ & $(0.004)$ \\
\hline \multicolumn{6}{|l|}{$\begin{array}{l}\text { Free school meal registration (Ref. Not } \\
\text { registered) }\end{array}$} \\
\hline \multirow[t]{2}{*}{ Registered } & 0.006 & 0.008 & 0.004 & 0.005 & 0.009 \\
\hline & $(0.003)$ & $(0.004)$ & $(0.005)$ & $(0.004)$ & $(0.005)$ \\
\hline \multicolumn{6}{|l|}{$\begin{array}{l}\text { Housing tenure (Ref. Owned/Private } \\
\text { rented) }\end{array}$} \\
\hline \multirow[t]{2}{*}{ Social rented } & $0.008^{* * *}$ & $0.009^{*}$ & $0.008^{*}$ & $0.009^{* *}$ & 0.006 \\
\hline & $(0.002)$ & $(0.003)$ & $(0.003)$ & $(0.003)$ & $(0.004)$ \\
\hline \multicolumn{6}{|l|}{$\begin{array}{l}\text { Scottish Index of Multiple Deprivation } \\
\text { (SIMD) (Ref. SIMD 5=least deprived) }\end{array}$} \\
\hline \multirow[t]{2}{*}{ SIMD4 } & 0.002 & 0.005 & -0.002 & 0.001 & -0.001 \\
\hline & $(0.003)$ & $(0.004)$ & $(0.005)$ & $(0.004)$ & $(0.005)$ \\
\hline
\end{tabular}




\begin{tabular}{|c|c|c|c|c|c|}
\hline \multirow[t]{2}{*}{ SIMD3 } & 0.001 & 0.005 & -0.004 & 0.003 & -0.005 \\
\hline & $(0.003)$ & $(0.003)$ & $(0.005)$ & $(0.003)$ & $(0.005)$ \\
\hline \multirow[t]{2}{*}{ SIMD2 } & 0.003 & 0.006 & -0.002 & 0.004 & -0.003 \\
\hline & $(0.003)$ & $(0.003)$ & $(0.005)$ & $(0.004)$ & $(0.006)$ \\
\hline \multirow[t]{2}{*}{ SIMD1=most deprived } & -0.002 & 0.002 & -0.006 & 0.000 & $-0.014^{* *}$ \\
\hline & $(0.004)$ & $(0.003)$ & $(0.006)$ & $(0.004)$ & $(0.005)$ \\
\hline \multicolumn{6}{|l|}{ Sex (Ref. Male) } \\
\hline \multirow[t]{2}{*}{ Female } & 0.002 & & & 0.003 & 0.002 \\
\hline & $(0.002)$ & & & $(0.002)$ & $(0.002)$ \\
\hline \multicolumn{6}{|l|}{ Place of residence (Ref. Urban) } \\
\hline \multirow[t]{2}{*}{ Rural } & -0.003 & -0.003 & -0.004 & & \\
\hline & $(0.002)$ & $(0.002)$ & $(0.003)$ & & \\
\hline \multicolumn{6}{|l|}{ Ethnicity (Ref. "White") } \\
\hline \multirow[t]{2}{*}{ "Other ethnic background" } & -0.005 & $-0.008^{* *}$ & -0.001 & -0.006 & -0.005 \\
\hline & $(0.004)$ & $(0.003)$ & $(0.007)$ & $(0.004)$ & $(0.004)$ \\
\hline \multirow[t]{2}{*}{ Child's age at start of secondary schooling } & $0.005^{*}$ & 0.005 & 0.005 & 0.005 & 0.002 \\
\hline & $(0.002)$ & $(0.003)$ & $(0.004)$ & $(0.003)$ & $(0.004)$ \\
\hline \multirow[t]{2}{*}{ Mother's age at birth } & $-0.000^{* *}$ & $-0.001^{* *}$ & -0.000 & $-0.000^{*}$ & -0.000 \\
\hline & $(0.000)$ & $(0.000)$ & $(0.000)$ & $(0.000)$ & $(0.000)$ \\
\hline \multicolumn{6}{|l|}{ School cohort (Ref. 2008) } \\
\hline \multirow[t]{2}{*}{2007} & 0.001 & 0.002 & 0.001 & 0.003 & -0.003 \\
\hline & $(0.002)$ & $(0.002)$ & $(0.002)$ & $(0.002)$ & $(0.002)$ \\
\hline $\mathrm{N}$ & 4620 & 2429 & 2191 & 3585 & 1035 \\
\hline
\end{tabular}

Source. Scottish Longitudinal Study, own calculations. Note. ${ }^{*} p<.05,{ }^{* *} p<.01,{ }^{* * *} p<.001$. Estimates shown as Average Marginal Effects (AMEs). Cluster-robust standard errors in parentheses. 
Table S6. Summary of logistic regressions predicting temporary exclusion among pupils in their final year of secondary schooling

\begin{tabular}{|c|c|c|c|c|c|}
\hline & Overall & Male & Female & Urban & Rural \\
\hline \multicolumn{6}{|l|}{ Parental education (Ref. First degree) } \\
\hline \multirow[t]{2}{*}{ College below degree } & 0.028 & $0.054^{*}$ & -0.002 & $0.052^{* *}$ & -0.040 \\
\hline & $(0.014)$ & $(0.024)$ & $(0.012)$ & $(0.017)$ & $(0.021)$ \\
\hline \multirow[t]{2}{*}{ Upper secondary qualification } & 0.001 & 0.010 & -0.009 & 0.006 & -0.011 \\
\hline & $(0.010)$ & $(0.017)$ & $(0.010)$ & $(0.011)$ & $(0.019)$ \\
\hline \multirow[t]{2}{*}{ Lower secondary qualification } & 0.009 & 0.007 & 0.010 & 0.017 & -0.006 \\
\hline & $(0.010)$ & $(0.016)$ & $(0.012)$ & $(0.011)$ & $(0.024)$ \\
\hline \multirow[t]{2}{*}{ No qualifications } & $0.034^{*}$ & $0.057^{*}$ & 0.007 & $0.039^{* *}$ & 0.014 \\
\hline & $(0.014)$ & $(0.022)$ & $(0.013)$ & $(0.015)$ & $(0.028)$ \\
\hline \multicolumn{6}{|l|}{$\begin{array}{l}\text { Parental class (Ref. Higher managerial and } \\
\text { professional occupations) }\end{array}$} \\
\hline \multirow[t]{2}{*}{ Intermediate occupations } & 0.001 & -0.005 & 0.009 & -0.009 & 0.032 \\
\hline & $(0.010)$ & $(0.017)$ & $(0.011)$ & $(0.012)$ & $(0.020)$ \\
\hline \multirow[t]{2}{*}{ Small employers and own account workers } & 0.020 & 0.005 & 0.039 & -0.007 & $0.066^{*}$ \\
\hline & $(0.015)$ & $(0.024)$ & $(0.020)$ & $(0.016)$ & $(0.028)$ \\
\hline \multirow[t]{2}{*}{ Lower supervisory and technical occupations } & $0.036^{* *}$ & $0.046^{*}$ & 0.025 & $0.035^{*}$ & 0.043 \\
\hline & $(0.014)$ & $(0.023)$ & $(0.015)$ & $(0.016)$ & $(0.028)$ \\
\hline \multirow[t]{2}{*}{ Semi-routine and routine occupations } & 0.013 & 0.016 & 0.009 & 0.008 & 0.020 \\
\hline & $(0.010)$ & $(0.017)$ & $(0.009)$ & $(0.011)$ & $(0.016)$ \\
\hline \multicolumn{6}{|l|}{$\begin{array}{l}\text { Free school meal registration (Ref. Not } \\
\text { registered) }\end{array}$} \\
\hline \multirow[t]{2}{*}{ Registered } & $0.041^{* *}$ & $0.054^{*}$ & $0.028^{*}$ & $0.028^{*}$ & $0.110^{* * *}$ \\
\hline & $(0.014)$ & $(0.022)$ & $(0.013)$ & $(0.014)$ & $(0.041)$ \\
\hline \multicolumn{6}{|l|}{ Housing tenure (Ref. Owned/Private rented) } \\
\hline \multirow[t]{2}{*}{ Social rented } & $0.020^{*}$ & 0.026 & 0.011 & $0.027^{*}$ & -0.004 \\
\hline & $(0.009)$ & $(0.015)$ & $(0.008)$ & $(0.011)$ & $(0.014)$ \\
\hline \multicolumn{6}{|l|}{$\begin{array}{l}\text { Scottish Index of Multiple Deprivation (SIMD) } \\
\text { (Ref. SIMD 5=least deprived) }\end{array}$} \\
\hline \multirow[t]{2}{*}{ SIMD4 } & 0.018 & 0.030 & 0.001 & 0.021 & -0.005 \\
\hline & $(0.011)$ & $(0.017)$ & $(0.012)$ & $(0.013)$ & $(0.026)$ \\
\hline
\end{tabular}




\begin{tabular}{|c|c|c|c|c|c|}
\hline \multirow[t]{2}{*}{ SIMD3 } & $0.021^{*}$ & $0.041^{* *}$ & -0.001 & $0.031^{* *}$ & -0.014 \\
\hline & $(0.010)$ & $(0.015)$ & $(0.012)$ & $(0.011)$ & $(0.024)$ \\
\hline \multirow[t]{2}{*}{ SIMD2 } & $0.028^{* *}$ & $0.045^{* *}$ & 0.010 & $0.026^{*}$ & 0.027 \\
\hline & $(0.011)$ & $(0.017)$ & $(0.013)$ & $(0.011)$ & $(0.031)$ \\
\hline \multirow[t]{2}{*}{ SIMD1=most deprived } & $0.024^{*}$ & $0.044^{*}$ & 0.002 & $0.025^{*}$ & 0.005 \\
\hline & $(0.012)$ & $(0.020)$ & $(0.013)$ & $(0.012)$ & $(0.045)$ \\
\hline \multicolumn{6}{|l|}{ Sex (Ref. Male) } \\
\hline \multirow[t]{2}{*}{ Female } & $-0.054^{* * * *}$ & & & $-0.061^{* * *}$ & $-0.026^{*}$ \\
\hline & $(0.006)$ & & & $(0.007)$ & $(0.012)$ \\
\hline \multicolumn{6}{|l|}{ Place of residence (Ref. Urban) } \\
\hline \multirow[t]{2}{*}{ Rural } & 0.001 & -0.013 & $0.019^{*}$ & & \\
\hline & $(0.008)$ & $(0.013)$ & $(0.009)$ & & \\
\hline \multicolumn{6}{|l|}{ Ethnicity (Ref. “White”) } \\
\hline \multirow[t]{2}{*}{ "Other ethnic background"" } & -0.025 & $-0.042^{*}$ & -0.006 & -0.020 & -1 \\
\hline & $(0.014)$ & $(0.021)$ & $(0.017)$ & $(0.017)$ & \\
\hline \multirow[t]{2}{*}{ Child's age at start of secondary schooling } & 0.003 & 0.008 & 0.000 & 0.008 & -0.010 \\
\hline & $(0.011)$ & $(0.018)$ & $(0.010)$ & $(0.012)$ & $(0.022)$ \\
\hline \multirow[t]{2}{*}{ Mother's age at birth } & -0.001 & -0.002 & -0.001 & -0.001 & -0.001 \\
\hline & $(0.001)$ & $(0.001)$ & $(0.001)$ & $(0.001)$ & $(0.001)$ \\
\hline \multicolumn{6}{|l|}{ School cohort (Ref. 2008) } \\
\hline \multirow[t]{2}{*}{2007} & $0.013^{*}$ & 0.015 & $0.013^{*}$ & $0.015^{*}$ & 0.013 \\
\hline & $(0.006)$ & $(0.010)$ & $(0.007)$ & $(0.007)$ & $(0.013)$ \\
\hline $\mathrm{N}$ & 4620 & 2429 & 2191 & 3585 & 1035 \\
\hline
\end{tabular}

Source. Scottish Longitudinal Study, own calculations. Note. ${ }^{*} p<.05,{ }^{* *} p<.01,{ }^{* * * *} p<.001$. Estimates shown as Average Marginal Effects (AMEs). Cluster-robust standard errors in parentheses; ${ }^{1}$ No estimate for ethnicity was calculated in rural areas because no child from "other ethnic backgrounds" was ever excluded. 